Anuario da Facultade de Dereito da Universidade da Coruña

Vol. 23 (2019), pp. 306-338

ISSNe: 2530-6324 || ISSN: 1138-039X

DOI: https://doi.org/10.17979/afdudc.2019.23.0.6021

\title{
EL PROCESO MONITORIO COMO INSTRUMENTO PARA LA TUTELA DEL CRÉDITO
}

\section{THE ADMONITORY TRIAL AS AN INSTRUMENT FOR THE PROTECTION OF THE CREDIT}

\author{
MARÍA DOLORES RAMÍREZ BENAVENTE \\ Doctoranda en Derecho Procesal. Universidad de Córdoba
}

\begin{abstract}
Resumen: Este artículo tiene como objetivo el examen del proceso monitorio introducido en España en el año 2000 y sus diversas modificaciones legislativas. Se estudiarán sus orígenes históricos y su naturaleza jurídica con carácter introductorio para facilitar su comprensión. Asimismo, se dividirá analíticamente el proceso en sus principales momentos con la intención de ofrecer una visión pormenorizada de cada una de sus fases y presentar la problemática inherente a cada una de ellas. Finalmente, se expondrán las conclusiones surgidas de este análisis con la finalidad de contribuir al conocimiento y práctica del proceso monitorio, teniendo en cuenta su carácter tutelar del crédito dentro de nuestro ordenamiento jurídico.
\end{abstract}

Palabras clave: monitorio, crédito, deudor, acreedor, tutela

\begin{abstract}
This article aims to examine the admonitory trial inserted in Spain in the year 2000 and his consecutive legal modifications. It will be studied the historical origins and legal nature of the admonitory trial with an introductory character to facilitate his comprehension. Likewise, it will be divided analytically the legal procedure in their principal moments with the intention to offers a detailed view from each one of their phases and to explain the difficulties attached to each and every ones. Finally, it will be show the arised conclusions from this analysis with the object of contibute to the knowledge and practice of the admonitory trial, considering his tutelary character of the credit inside our legal order.
\end{abstract}

Keywords: admonitory trial, credit, debtor, creditor, tutelary

Sumario: I. INTRODUCCIÓN. II. ORIGEN Y NATURALEZA JURÍDICA. III. LA COMPETENCIA JURISDICCIONAL. IV. SOLICITUD E INICIO DEL PROCEDIMIENTO. V. CONTROL JUDICIAL DE LAS CLÁUSULAS ABUSIVAS. VI. EL REQUERIMIENTO DE PAGO. VII. EL ESCRITO DE OPOSICIÓN. VIII. EL JUICIO DECLARATIVO. IX. LA EJECUCIÓN. X. CONCLUSIONES. XI. BIBLIOGRAFÍA. 


\section{INTRODUCCIÓN}

El procedimiento monitorio fue incorporado al ordenamiento jurídico español en el año 2000 con ocasión de la profunda reforma de la legislación procesal acometida en este año, no obstante, este proceso era ya una constante en el conjunto de los países europeos y además goza de una larga historia en el continente. Es decir, que para los juristas españoles se trate de una novedad no significa que se trate de una institución novedosa y, más bien, se está en presencia de una técnica procesal muy antigua en el tiempo y con una gran implantación continental.

Este trabajo de investigación tratará de dar noticia de ese hecho y relatar sucintamente la historia del proceso monitorio, así como de sus diversas modalidades o tipos en los diferentes países en los que se viene aplicando desde hace siglos. Está más allá de este objetivo buscar las razones de su tardía implantación en España, que, sin duda, podría haberse producido mucho antes en el tiempo; pues siempre ha existido la necesidad de un proceso especial destinado a la rápida satisfacción de crédito y desde hace varios siglos esta es la finalidad a la que está llamado el proceso monitorio.

La técnica monitoria es relativamente sencilla y consiste en invertir el contradictorio, de modo tal que la carga de la prueba recaerá sobre el deudor. Además, se privilegia al acreedor permitiendo la rápida obtención de un título ejecutivo en el caso de que el deudor no comparezca o no se oponga fundadamente. Sólo un exceso de celo garantista o una legislación tradicionalmente centrada en la protección del deudor pueden justificar que este longevo proceso haya tardado tanto en introducirse en España. Aún puede resultar más llamativo el hecho de que su introducción venga prácticamente ordenada por la legislación comunitaria, casi como un imperativo de armonización jurídica al que España tenía que adaptarse.

En todo caso, el procedimiento monitorio ha acabado por traspasar las fronteras españolas y hoy ha llegado a ser el proceso más utilizado para la reclamación de deudas dinerarias y esto exige un análisis pormenorizado del mismo. El trabajo que aquí se presenta trata de hacerse eco de importantes contribuciones doctrinales y compendiar las tesis, problemáticas y conclusiones ofrecidas por la dogmática procesalista y la jurisprudencia de los tribunales, con la finalidad de facilitar el conocimiento aproximativo a la institución monitoria.

Esta investigación extracta las posiciones doctrinales de mayor relevancia en las cuestiones más problemáticas acerca del proceso monitorio, con la intención de facilitar el estudio y comprensión del mismo; sin perjuicio, de que a lo largo de estas páginas puedan encontrarse algunos posicionamientos propios al hilo de las tesis discutidas.

\section{ORIGEN Y NATURALEZA JURÍDICA}


En el presente epígrafe se va a examinar la figura del proceso monitorio en nuestro país. Concretamente, se examinará la historia de este proceso en España desde su introducción en el año 2000, los antecedentes históricos de la misma y las sucesivas reformas que han modificado la práctica desde su introducción.

Asimismo, se intentará dar respuesta a su discutida naturaleza jurídica teniendo en cuenta las diferentes tesis que, al respecto, se han formulado. Finalmente se sintetizarán los diferentes modelos de proceso monitorio de países vecinos, como son Austria, Alemania e Italia, para comprobar cuál es el modelo que inspira al legislador español.

\section{Historia del proceso monitorio}

El estudio más completo que se puede encontrar en la doctrina se debe al profesor Tomás y Valiente, publicado en 1960 en la Revista de Derecho Procesal. En este extenso artículo el afamado historiador del derecho realiza un recorrido histórico desde los orígenes del proceso monitorio en las ciudades estado italianas de la Baja Edad Media hasta la Ley de Enjuiciamiento Civil de 1881 (en adelante, LEC). En este decurso histórico debe destacarse desde el inicio, que el proceso monitorio nunca tuvo un reconocimiento legal expreso hasta el año 2000, con la promulgación de la actual LEC; pero como el estudio de Tomás y Valiente demuestra, este proceso no fue desconocido en la práctica de los tribunales y en las costumbres de los foros ${ }^{1}$.

Parece ser que el proceso monitorio surge en la Baja Edad Media, en Italia, paralelamente al crecimiento de los intercambios comerciales de las ciudades estado italianas (Génova, Florencia y Venecia) con el objetivo de proteger los intereses de los acreedores y dotarles de manera rápida de un título ejecutivo en aquellos casos en que sus créditos no se viesen protegidos por una garantía formal ${ }^{2}$.

Con esta intención nace el "mandatum de solvendo cum clausula iustificativa", como escribe Tomás y Valiente: "El acreedor insatisfecho que no poseyese un título ejecutivo y no se resignase a acudir al proceso ordinario, se presentaba ante el juez y solicitaba de él la emisión del mandatum de solvendo cum clausula iustificativa. Si el juez accedía a la petición del acreedor (y para ello ni siquiera se necesitaba aportar prueba documental), emitía el mandatum, orden de pago dirigida contra el deudor"3. Esta orden de pago iba acompañada de las siguientes opciones: o pagaba, o comparecía ante el juez, o ninguna de las anteriores. Si pagaba, todo quedaba resuelto; si se oponía, se iniciaba un procedimiento ordinario; y si no realizaba ninguna de estas acciones, el mandato se convertía en definitivo y otorgaba al acreedor un título ejecutivo para la satisfacción de su crédito ${ }^{4}$.

\footnotetext{
${ }^{1}$ TOMÁS Y VALIENTE, F., "Estudio histórico-jurídico del proceso monitorio", Revista de Derecho Procesal, (1960), pp. 135-138.

${ }^{2}$ CORREA DELCASSO, J.P., "El proceso monitorio en el Derecho comparado: diez puntos clave para su correcta implementación en los países de América Latina", en AAVV., El proceso monitorio en América Latina. Pasado, presente y futuro, Temis, 2013, Bogotá, pp. 21-23.

${ }^{3}$ TOMÁS Y VALIENTE, F., "Estudio histórico-jurídico...", op. cit., p. 45.

${ }^{4}$ Ibidem, p. 46.
} 
Como vemos, este procedimiento de tutela del crédito surgido en Italia ${ }^{5}$, guarda muchísima semejanza con el proceso monitorio actual. Concretamente, sus líneas esenciales son las mismas, a saber: a) que la obligación cuya satisfacción se incoa no conste en un título ejecutivo, b) que la orden de pago ofrezca la alternativa de cumplir o comparecer, c) que transcurrido el plazo para comparecer adquiera el mandato fuerza ejecutiva $\mathrm{y}, \mathrm{d}$ ) que la comparecencia del demandado transforme el proceso en ordinario $^{6}$.

Se han querido ver similitudes entre el proceso monitorio y las órdenes de pago del Consulado del Mar de Barcelona, el llamado manament de pago introducido en el primer tercio del siglo XV, y cuyo origen se especula que pudo ser la influencia italiana. Sin embargo, no se trata de un auténtico proceso monitorio sino más bien de un proceso sumario ejecutivo porque la resolución acerca de la ejecución de mandato no es apelable $^{7}$. El único rastro de la existencia del monitorio en nuestro país lo encontramos en la literatura jurídica del siglo XIX, pero no en sus fuentes legales. En este sentido, se debe hacer mención a los estudios de Nougués Secal y Juan María Rodríguez; ambos autores, el primero en Aragón y el segundo en Sevilla, a propósito del comentario del artículo 227 LEC de 1855 dan noticia de la práctica extra legal del monitorio en estos territorios.

No obstante, por considerarse en su conjunto todas las prácticas extralegales como perniciosas y abusivas (sin hacer distinción entre ellas) fueron definitivamente desterradas de los textos legales en la LEC de 1855 y en su reforma de $1881^{8}$.

Esta debe ser la razón de que no encontremos ningún texto legal referido al monitorio en la historia jurídica de España y se deba esperar hasta el año 2000, con la promulgación de la actual LEC para su incorporación. Ello se deberá más a la influencia del derecho comunitario que a la fuerza de nuestra tradición procesal. Ahora bien, desde el año 2000 la institución del monitorio ha sufrido diferentes modificaciones, siendo la más importante de ellas la introducida por la ley 13/2009 de reforma de la legislación procesal para la implantación de la nueva oficina judicial, que ha transformado la naturaleza jurisdiccional del proceso dotando de considerables poderes al Letrado de la Administración de Justicia, en adelante LAJ, suponiendo para algunos autores la desjudicialización del procedimiento 9 .

\section{Naturaleza jurídica del proceso monitorio}

La doctrina siempre ha presentado dudas acerca de la naturaleza jurídica de este procedimiento. Se discute, especialmente, si posee o no una naturaleza jurisdiccional, si se trata de un proceso ejecutivo o declarativo y, de ser un proceso declarativo, si tiene una naturaleza mixta o especial. Entre los autores que consideran que el proceso monitorio se trata de un procedimiento judicial, pero no jurisdiccional, se sitúa Cortés Domínguez o Bermúdez Requena. El profesor Cortés considera que el procedimiento no busca que se declare el derecho de crédito, sino que tan sólo sea

\footnotetext{
${ }^{5}$ QUÍLEZ MORENO, J.M., El proceso monitorio: estudio doctrinal, jurisprudencial y futura realidad de la e-justicia, La Ley, 2011, Madrid, p. 29.

6 TOMÁS Y VALIENTE, F., "Estudio histórico-jurídico...", op. cit., p. 69.

${ }^{7}$ Ibidem, pp. 54-59.

${ }^{8}$ Ibidem, pp. 72-105.

${ }^{9}$ QUÍLEZ MORENO, J.M., El proceso monitorio..., op. cit., p. 38.
} 
protegido por el LAJ ordenando el pago ${ }^{10}$. Bermúdez Requena, en el mismo sentido, entiende que los poderes otorgados por la reforma de 2009 al LAJ suponen una desjudicialización del proceso y que, por ello, se trata de un proceso judicial pero no jurisdiccional ${ }^{11}$. En cambio, Martínez Beltrán de Heredia, considera que en el proceso monitorio no hay propiamente una fase declarativa sino tan sólo un control inicial de la petición y por ello, lo encuadra más dentro de los procesos sumarios ejecutivos ${ }^{12}$.

En un sentido diferente, se manifiesta Gómez Martínez, quien considera que el monitorio es un proceso especial en razón de la materia y en razón de su estructura particular, caracterizada por la inversión del contradictorio. Además, afirma su naturaleza declarativa puesto que tiene como finalidad obtener un título ejecutivo ${ }^{13}$. Una tesis ecléctica mantiene Gómez Colomer, quien divide el proceso monitorio en dos fases: una primera declarativa y una segunda ejecutiva ${ }^{14}$.

En todo caso, se trata de una discusión meramente teórica y de alcance doctrinal. Pero lo que ningún autor discute es la funcionalidad práctica del proceso monitorio y su utilidad en orden a la protección judicial del crédito. Esta discusión teórica no es indiferente en el orden práctico, pues dependiendo de la naturaleza jurídica del monitorio le serán de aplicación unas u otras normas supletorias; bien las correspondientes a un proceso declarativo o bien las normas aplicables a los procesos de ejecución. En mi opinión, este procedimiento tiene una naturaleza declarativa, puesto que, en todo caso el acreedor deberá abrir la vía ejecutiva para la satisfacción de su deuda; siendo el proceso monitorio en sí una mera declaración de su derecho de cobro.

\section{El proceso monitorio en la legislación extranjera}

Existen tres grandes modelos históricos de proceso monitorio: el modelo austriaco (Rechtsbot), el alemán (Mahnverfahren), y el italiano (procedimiento d'ingiunzione). El primero de ellos, el modelo austriaco, es una variación del modelo alemán, pero difiere de él en que solo se aplica en casos cuya cuantía sea inferior a un determinado límite ${ }^{15}$. El procedimiento alemán es esencialmente oral y su dinámica es muy sencilla: un acreedor cuya pretensión no conste en título ejecutivo acude al juez para que dicte contra el deudor un mandamiento de pago sin entrar a estudiar el fondo del asunto. El deudor puede oponerse en el plazo de una semana sin motivación, en cuyo caso se transforma en procedimiento ordinario; o bien, pagar y cerrar el proceso, o no hacer nada y se transforma este mandato en título ejecutivo. En cambio, en el procedimiento italiano se distinguen dos modalidades: un procedimiento monitorio puro y un procedimiento monitorio documental. En el modelo puro el juez dicta mandato de

\footnotetext{
${ }^{10}$ CORTÉS DOMÍNGUEZ, V. y MORENO CATENA, V., Derecho procesal civil. Parte especial, $9^{\mathrm{a}}$ ed., Tirant lo Blanch, 2017, Valencia, p. 186.

${ }^{11}$ BERMÚDEZ REQUENA, J.M., Proceso monitorio. Evolución legislativa, doctrinal y jurisprudencial, Jurúa, 2017, Lisboa, p. 23.

${ }^{12}$ MARTÍNEZ BELTRÁN DE HEREDIA, F., El proceso monitorio. Teoría y práctica, Difusión jurídica y temas de actualidad, 2007, Madrid, p. 32.

${ }^{13}$ AAVV., Comentarios a la nueva ley de enjuiciamiento civil, tomo III, Lex nova, 2001, Barcelona, p. 3.804 .

${ }^{14}$ GÓMEZ COLOMER, J.L., "Comentarios prácticos a los artículos 812 a 818 del capítulo I del título III del libro IV de la Ley de Enjuiciamiento Civil: del proceso monitorio", en SOLAZ, E., Ejecución de títulos extrajudiciales. Juicio cambiario y monitorio, Consejo General del Poder Judicial, 2005, Madrid, pp. 393-394. Aún hoy se mantiene en esta posición. Vid., AAVV., Derecho jurisdiccional II. Proceso civil, $25^{\text {a }}$ ed., Tirant lo Blanch, 2017, Valencia, p. 823.

${ }^{15}$ TOMÁS Y VALIENTE, F., "Estudio histórico-jurídico...", op. cit., p. 34.
} 
pago sin necesidad de aportar prueba alguna del derecho del acreedor; por el contrario, en el documental, la pretensión del acreedor debe estar fundada en prueba escrita. Con el paso de los años, ha predominado en la práctica del derecho italiano el modelo documental ${ }^{16}$.

\section{LA COMPETENCIA JURISDICCIONAL}

En el sistema constitucional español, la jurisdicción es única y está atribuida al Estado en exclusiva, de modo que puede afirmarse que tiene potestad jurisdiccional exclusiva para cualquier ámbito y materia jurídica. No obstante, ello no quiere decir que cualquier tribunal pueda conocer de cualquier materia. El ejercicio de jurisdicción y de la potestad jurisdiccional aneja a esta función se encuentra dividido, por así decirlo, en ramas jurídicas, y así encontramos la jurisdicción civil, penal, contenciosoadministrativa y laboral. Ahora bien, existe una norma de cierre en virtud de la cual si un asunto no está expresamente atribuido a una jurisdicción corresponderá su conocimiento al orden civil (art. 9.2 Ley Orgánica del Poder Judicial, en adelante LOPJ). A esto se le conoce como la vis attractiva de la jurisdicción civil ${ }^{17}$.

La potestad jurisdiccional obedece en nuestro sistema al principio de competencia; en virtud del cual, cada tribunal conocerá y resolverá acerca de los asuntos que legalmente vengan predeterminados en la ley. La legislación reparte estas competencias en virtud de tres principales criterios: el objeto del proceso, el ámbito territorial del foro y su funcionalidad. Comúnmente, es lo que se conoce como competencia objetiva, territorial y funcional, tal y como se examinará a continuación.

Basta ahora con señalar que la jurisdicción es un requisito previo al proceso, sin cuyo cumplimiento no puede iniciarse por el juez un conocimiento jurídico de la pretensión, ni por supuesto resolverse. Además, este requisito deberá ser examinado de oficio por el propio órgano jurisdiccional ${ }^{18}$.

\section{Competencia objetiva}

La competencia objetiva determina qué órgano debe conocer del proceso en primera instancia atendiendo al objeto del mismo, con carácter exclusivo y excluyente. Generalmente, se establece en virtud de dos criterios: la materia del proceso y la cuantía del mismo ${ }^{19}$. A estos dos, habría que añadir un tercero que atribuye competencia a determinados tribunales en función de los sujetos del proceso, en cuyo caso habrá que tener en cuenta si concurre un aforamiento o norma que atribuya la resolución de la controversia a un tribunal concreto en razón de la persona demandada ${ }^{20}$. Estos criterios funcionan de manera subsidiaria, es decir, primero se impone el criterio subjetivo, luego la competencia en razón de la materia y en último lugar el criterio cuantitativo ${ }^{21}$.

\footnotetext{
${ }^{16}$ Ibidem, p. 35-38.

${ }^{17}$ JUAN SÁNCHEZ, R., Introducción al derecho procesal, Aranzadi, 2017, Pamplona, pp. 150-151.

${ }^{18}$ GIMENO SENDRA, V., Introducción al derecho procesal, UNED, 2015, Madrid, p. 214.

${ }^{19}$ ARMENTA DEU, T., Lecciones de derecho procesal civil, Marcial Pons, 2017, Madrid, p. 63.

${ }^{20}$ CUBILLO LÓPEZ, I., Aspectos fundamentales del derecho procesal civil, La Ley, 2016, Madrid, p. 203.

${ }^{21}$ Ibidem, p. 204.
} 
La competencia objetiva del tribunal es un requisito esencial para permitir la acumulación de acciones (art. 73 LEC). Además, para darse dicha acumulación, también deberán reunirse dos requisitos materiales: que los procesos sean de la misma naturaleza y que la acumulación no persiga defraudar las leyes procesales en materia de jurisdicción o procedimiento ${ }^{22}$.

\section{Competencia territorial}

Toda vez que se ha establecido la competencia objetiva de los tribunales, hay que determinar cuál es el tribunal del territorio español a quien corresponde el conocimiento del proceso. Tradicionalmente, la competencia territorial era disponible por las partes mediante el llamado acuerdo de sumisión que se imponía sobre los llamados fueros legales. No obstante, con el tiempo se ha producido una inversión y, progresivamente, son las normas de competencia territorial las que se imponen sobre la voluntad de las partes, es decir, la prevalencia de los llamados fueros legales imperativos previstos en la $\mathrm{LEC}^{23}$. Estos fueros se comprenden en el artículo 52 LEC; siendo imperativos los señalados en sus apartados $1^{\circ}$ y $4^{\circ}$ a $15^{\circ}$, de acuerdo con lo recogido en el artículo 54 de la misma ley. Son normas de ius cogens, por lo que su observancia debe garantizarse de oficio ${ }^{24}$.

Cuando no existen fueros imperativos, la competencia territorial es disponible por las partes, en virtud de sumisión expresa o tácita. La sumisión expresa aparece regulada en el artículo 55 LEC y puede ser previa al litigio o bien posterior, pero siempre deberá versar sobre un órgano con competencia objetiva (art. 54.3 LEC) y habrá de respetar las normas de reparto de los asuntos (art. 57 LEC). La sumisión expresa no será válida cuando se trate de contratos de adhesión o condiciones generales de la contratación, ni tampoco cuando una de las partes sea un consumidor o usuario $(\operatorname{art} .54 .2)^{25}$.

La sumisión tácita se materializa presentando la demanda ante el tribunal en el que se quiera atribuir competencia territorial, y siempre que el demandado no impugne esta competencia se entenderá, tácitamente, sometido al tribunal ${ }^{26}$.

Por último, cuando no concurra un fuero legal imperativo, ni sumisión de las partes, se aplicarán los foros dispositivos previstos en los artículos 50 y 51 LEC, que generalmente, atribuyen competencia al tribunal del domicilio del demandado ${ }^{27}$.

El demandado podrá denunciar, mediante declinatoria, la falta de competencia del tribunal, tanto la falta de competencia objetiva como la de competencia territorial. En este sentido, la LEC concibe la declinatoria como el único medio procesal a través del cual cuestionar la jurisdicción del tribunal: bien porque el conocimiento del proceso corresponda a un órgano de otra rama jurisdiccional o a un tribunal extranjero, o bien porque la cuestión esté sometida a arbitraje o a mediación civil y mercantil (artículo 63

\footnotetext{
22 BANACLOCHE PALAO, J., Aspectos fundamentales de derecho..., op . cit., p. 248.

${ }^{23}$ CUBILlO LÓPEZ, I., Aspectos fundamentales de derecho..., op. cit., p. 206.

${ }^{24}$ ARMENTA DEU, T., Lecciones de derecho procesal..., op. cit., p. 68.

${ }^{25}$ CUBILlO LÓPEZ, I., Aspectos fundamentales de derecho..., op. cit., p. 207.

${ }^{26}$ Idem.

${ }^{27}$ ARMENTA DEU, T., Lecciones de derecho..., op. cit., p. 69.
} 
LEC). La declinatoria se habrá de plantear ante el tribunal que esté conociendo del asunto y cuya jurisdicción o competencia se impugna ${ }^{28}$.

\section{Competencia funcional}

En último lugar, encontramos la competencia funcional, que se establece en virtud de las conexiones que presenta el asunto con un proceso del que ya esté conociendo un determinado tribunal. En este sentido, el tribunal competente para conocer de un pleito lo es también para resolver sobre sus incidencias y ejecutar las sentencias, transacciones, convenios, etc. (art. $61 \mathrm{LEC})^{29}$. El artículo 62 señala que no se admitirán a trámite los recursos que se dirijan a un tribunal carente de competencia funcional, sin embargo, esta competencia en el caso de los recursos variará en función de que sean devolutivos o no devolutivos; es decir, que deba resolver el mismo tribunal cuya resolución se impugna, o bien deba resolverlo un tribunal superior ${ }^{30}$.

\section{La competencia en el procedimiento monitorio}

La competencia objetiva de los procesos monitorios corresponde al juzgado de primera instancia; si bien, el ejercicio de la competencia se reparte entre el juez y el LAJ, a quien corresponde la admisión de la petición monitoria. Territorialmente se establece el fuero de carácter imperativo a favor del juzgado de primera instancia del domicilio o residencia del deudor y, en su defecto, el juzgado donde se encuentre el deudor a efectos de requerimiento de pago ${ }^{31}$. El carácter imperativo del fuero tiene su razón de ser en la finalidad del proceso monitorio, que no es otra que la rápida obtención de un título ejecutivo ${ }^{32}$.

De acuerdo con el artículo 53 LEC, nada impide la acumulación de acciones en el procedimiento monitorio, pero se pueden dar los siguientes problemas: a) que las cantidades debidas por los deudores sean diferentes, b) que unos deudores se opongan y otros no, y c) que los deudores tengan domicilios diferentes. Ello ha tenido como consecuencia que algunos tribunales no admitan la acumulación de acciones en el proceso monitorio ${ }^{33}$. No obstante, algunos autores consideran que estas dificultades no son suficientes para impedir la acumulación de acciones y que esta no perjudicaría en ningún caso los derechos del deudor ${ }^{34}$.

Planchadell considera que es posible la acumulación objetiva siempre que se respeten las reglas del artículo 53 LEC, esto es, la competencia corresponderá al juzgado del lugar que conozca de la acción que sea fundamento de las demás; en su defecto, aquél que deba conocer del mayor número de las accionas acumuladas y, en último término, el del lugar que corresponda a la acción más importante cuantitativamente. En el caso de la acumulación subjetiva, esto es, cuando la petición

\footnotetext{
${ }^{28}$ MONTERO AROCA, J., El proceso civil, Tirant lo blanch, 2016, Valencia, pp. 416-418.

${ }^{29}$ ARMENTA DEU, T., Lecciones de derecho..., op. cit., p. 72.

${ }^{30}$ CUBILLO LÓPEZ, I., Aspectos fundamentales de derecho..., op. cit., p. 205.

${ }^{31}$ Es decir, no cabe sumisión, como se puede comprobar en la lectura de la STS 20-3-2012, RJ/690391. También la STS 29-4-2015, RJ/815528, y STS 2-4-2013, RJ/715247.

32 PLANCHADELl GARGALlO, A., La tutela del crédito en el proceso monitorio, La Ley, 2015, Madrid, pp. 81-82.

${ }^{33}$ PEITEADO MARISCAL, P. y CUBILLO LÓPEZ, I., Instrumentos procesales para la tutela judicial del crédito, Dykinson, 2018, Madrid, p. 119. En este sentido, Vid. STS 11-2-2016, RJ/840866.

${ }^{34}$ BERMÚDEZ REQUENA, J.M., Proceso monitorio..., op. cit., p. 62.
} 
monitoria se presente contra varios deudores y corresponda la competencia a jueces de más de un lugar, la demanda podrá presentase ante cualquier de ellos a elección del demandante ${ }^{35}$. Siendo posibles ambos supuestos en el proceso monitorio, nada indica que no se puedan dar situaciones problemáticas derivadas de dicha acumulación, tanto objetiva como subjetiva. Quizás la cuestión más controvertida que pueda darse sea consecuencia de la acumulación subjetiva, por las diferentes actitudes de los deudores o bien por el régimen de responsabilidad que haya entre ellos, si la responsabilidad que deriva de la obligación que se pretende hacer cumplir es solidaria o mancomunada.

Existe un problema relativo a la competencia objetiva en los procesos monitorios que no ha sido resuelto en las sucesivas reformas. Se trata de la posible competencia de los juzgados de lo mercantil cuando se reclamen créditos de los dispuestos en el art. 812 LEC, que se encuentren dentro de las materias que serán competencia de los juzgados de los mercantil, según el art. 86 ter LOPJ (pretensiones al amparo de normativa de transporte, condiciones generales de la contratación, cláusulas abusivas, propiedad intelectual, etc. $)^{36}$.

Los propios juzgados de lo mercantil han rechazado su competencia considerando que su jurisdicción se justifica por la complejidad de los asuntos mercantiles que requieren de una cierta especialización, que no es necesaria para la simple reclamación de cantidades objeto del proceso monitorio. En cambio, las audiencias provinciales han considerado que las cuestiones de competencia son asuntos que responden a criterios objetivos, independientemente de su carácter complejo o no. En este sentido, la SAP de Madrid Rec: 156/2006, establece que la competencia asignada en el artículo 86 ter 2 de LOPJ a los Juzgados de lo Mercantil se trata de una competencia en razón de la materia y no del procedimiento. De modo que, si legalmente se atribuye competencia a los juzgados mercantiles, estos no pueden negarse a conocer del asunto ${ }^{37}$.

El profesor Gómez Amigo comparte este último criterio y considera que la competencia de los juzgados mercantiles se establece objetivamente en el artículo 86 ter 2 de la LOPJ, que atribuye el conocimiento de cualquier reclamación dineraria relativa a estas materias a los juzgados de lo mercantil y que se impone al artículo 813 LEC $^{38}$. En un sentido similar se pronuncia Planchadell, quien, a efectos de deslindar la competencia objetiva de los juzgados mercantiles, considera que no puede obviarse que junto a la petición inicial del proceso monitorio deben acompañarse los documentos acreditativos de la deuda y de su origen; esto último nos revelará la naturaleza mercantil o civil de la deuda, y en su virtud habrá de apreciarse la competencia de oficio por el tribunal (art. 48 LEC) $)^{39}$.

Por otro lado, la determinación de la falta de competencia territorial en los procesos monitorios puede producirse de oficio o a instancia de parte. El control de oficio de la competencia objetiva en virtud del artículo 48.1 LEC puede producirse en cualquier momento, con carácter previo a la admisión a trámite de la demanda o en

\footnotetext{
${ }^{35}$ PLANCHADELL GARGALLO, A., La tutela del crédito..., op. cit., p. 82.

${ }^{36}$ Ibidem, p. 83.

${ }^{37}$ Ibidem, p. 84.

38 GÓMEZ AMIGO, L., "La evolución del proceso monitorio. En particular, su reforma por la ley 42/2015 de 5 de octubre". Práctica de tribunales, n. 126, (2017), p. 9.

${ }^{39}$ PLANCHADELL GARGALLO, A., La tutela del crédito..., op. cit., pp. 85-86.
} 
cualquier otro momento posterior en que el juzgado advierta su falta de competencia. En el caso de la competencia territorial, y siguiendo las normas establecidas con carácter general para los procesos declarativos (artículo 58 LEC) deberá controlarse inmediatamente después de la presentación de la demanda. En virtud del artículo 813 LEC, podrá inadmitirse a trámite la solicitud inicial y se decretará el archivo por el LAJ, al no poder determinarse el domicilio del deudor, al igual que cuando se tenga conocimiento de su domicilio en un partido judicial distinto ${ }^{40}$.

Además, el deudor puede plantear la falta de competencia territorial u objetiva mediante la correspondiente declinatoria y no tener que esperar a sustanciar esta falta de competencia en el escrito de oposición. El plazo en este caso será el establecido en el artículo 64.1 LEC, es decir, 10 días para interponer la declinatoria y no el de 20 días para la oposición al proceso monitorio del artículo 818 de la misma ley. Al igual ocurre en los procesos declarativos ordinarios, pues el plazo para interponer la declinatoria es más breve y no coincide con el plazo para contestar a la demanda (en el juicio verbal, en cambio, sí coincide) $)^{41}$. En el caso del proceso monitorio, bien es cierto que la declinatoria podrá plantearse en el mismo escrito de oposición ya que en este se alegarán tanto cuestiones procesales como sustantivas.

\section{SOLICITUD E INICIO DEL PROCEDIMIENTO}

\section{Legitimación}

La legitimación activa corresponde al acreedor que reclama, y que se atribuye la titularidad del crédito, lo que generalmente vendrá reflejado en la base documental que sostiene la petición monitoria. Si se trata de un contrato de venta o suministro será el vendedor el legitimado activamente, y si se reclaman rentas lo será el arrendador. En este asunto, se plantea Ibarra Sánchez la posible legitimación de la junta de arrendatarios y las administraciones públicas; pero lo cierto es que nuestro ordenamiento jurídico aún no se ha pronunciado sobre la legitimación de la junta de arrendatarios, por lo que no se puede afirmar a ciencia cierta. En cambio, sí que deben considerarse legitimadas activamente determinadas instituciones de derecho público en cuanto tengan la condición de acreedores para reclamar deudas y, además, contarán con el beneficio del fuero territorial a su favor establecido en el art. 15 de la ley 52/1997 de asistencia jurídica del Estado e Instituciones Públicas. Este beneficio consiste en tener la posibilidad de presentar la demanda en la capital de provincia y que, en cuanto afecte al monitorio, supondrá la necesidad de dirigir exhorto al juzgado del domicilio del deudor ${ }^{42}$.

Planchadell, recuerda la necesidad de que quien afirma su condición de acreedor haya de reunir los requisitos establecido en el art. $812 \mathrm{LEC}$, esto es, que pueda acreditar documentalmente dicha condición, y que más adelante se examinará ${ }^{43}$.

\footnotetext{
40 BERMÚdEZ REQUENA, J.M., Proceso monitorio..., op. cit., pp. 56-59. Vid., STS 16-6-2004 RJ/75933, y STS 17-5-2005 RJ/75924.

${ }^{41}$ Ibidem, p. 59. Especialmente es ilustrativa la STS 12-7-2007, RJ/123000 que mantiene este mismo criterio.

${ }^{42}$ IBARRA SÁNCHEZ, J.L., Aspectos fundamentales del procedimiento monitorio civil, La Ley, 2016, Madrid, pp. 105-107.

${ }^{43}$ PLANCHADELL GARGALLO, A., La tutela del crédito..., op. cit., p. 34.
} 
En cuanto a la legitimación pasiva, se debe entender que corresponde a la persona que figure como deudor en el documento acreditativo de la petición monitoria, con la salvedad de lo dispuesto para los procesos monitorios de la Ley de Propiedad Horizontal, en adelante LPH, en virtud de lo cual, estarán legitimados pasivamente el propietario anterior del inmueble y el titular registrar (art. 9.1 LPH). Además, también se ha de tener en cuenta el art. 1209 del Código Civil, en adelante CC, para los casos de subrogación y cesión de créditos ${ }^{44}$.

Existen supuestos de legitimación pasiva especialmente problemáticos, Ibarra Sánchez sintetiza este conjunto de situaciones excepcionales como son: la herencia yacente, la condición de demandada de la Administración Pública y la legitimación pasiva de los coarrendatarios ${ }^{45}$. Por lo que respecta a la herencia yacente, el actor tiene la carga de proporcionar al juzgado cuantos datos tenga en su alcance para facilitar la localización y aviso de los familiares llamados a la herencia $\mathrm{y}$, de no hacerlo, se archivará o se rechazará la petición monitoria ${ }^{46}$. La condición de deudora de la Administración Pública en este tipo de procesos se ha dado en conflictos de propiedad horizontal a propósito de las viviendas protegidas en las que la Administración ocupa la posición de arrendadora y propietaria y esta intenta eludir las obligaciones y la responsabilidad legal inherentes a su condición de propietarias. Se entiende que no hay ningún obstáculo para que la comunidad de propietarios pueda instar el procedimiento monitorio del art. $21 \mathrm{LPH}$ contra la Administración ${ }^{47}$. Finalmente, por lo que se refiere a los coarrendatarios, se debe señalar la enorme problemática que supuso en la instauración del proceso monitorio en el año 2000, pero que hoy, tras la reforma de 2009 es una cuestión absolutamente pacífica al establecer el régimen solidario del pago de las rentas y la inexistencia de litisconsorcio pasivo necesario ${ }^{48}$.

\section{Objeto de proceso}

El objeto del proceso monitorio lo constituye la pretensión de obtener satisfacción respecto de un derecho de crédito sobre una deuda que cumpla las siguientes condiciones: dineraria, líquida, determinada, vencida y exigible (art. 812 LEC). El proceso solo puede versar sobre obligaciones dinerarias, esto es, aquellas que tienen por objeto una obligación pecuniaria consistente en la entrega de una cantidad de dinero como instrumento de cambio, bien en moneda nacional o extranjera si la relación causal se pactó en tales términos en consonancia con el artículo 577.1 LEC $^{49}$. En segundo lugar, debe tratarse de una deuda líquida, es decir, no sólo aquella cuya cuantía esté fijada de manera cierta y concreta, en números o en letras, sino también la que pueda establecerse por el acreedor a través de sencillas operaciones aritméticas sin necesidad de instar un procedimiento judicial para precisarlo ${ }^{50}$. A su vez, la deuda debe estar determinada, detallando la cantidad principal y los intereses remuneratorios si hubiesen sido pactados ${ }^{51}$. Otro de los requisitos es que la deuda debe haber vencido, esto es, que se haya cumplido el plazo de pago establecido, no siendo posible utilizar el

\footnotetext{
${ }^{44}$ BERMÚDEZ REQUENA, J.M., Proceso monitorio..., op. cit., p. 111.

${ }^{45}$ IBARRA SÁNCHEZ, J.L., Aspectos fundamentales del procedimiento ..., op. cit., pp. 108-115.

46 Ibidem, p. 108.

${ }^{47}$ Ibidem, p. 110.

${ }^{48}$ Ibidem, p. 115.

${ }^{49}$ BERMÚDEZ REQUENA, J.M., Proceso monitorio..., op. cit., p. 68.

${ }^{50}$ PEITEADO MARISCAL, P. y CUBILLO LÓPEZ, I., Instrumentos procesales..., op. cit., p. 116.

${ }^{51}$ Idem.
} 
monitorio para deudas futuras ${ }^{52}$. Finalmente, la deuda tiene que ser exigible, por lo que no debe ser una deuda sometida a condición ni a cualquier tipo de contraprestación puesto que el objeto del monitorio es proporcionar un título ejecutivo. Por lo que se refiere a la cuantía de la deuda, la Ley 37/2011 de medidas de agilización procesal, estableció que la deuda dineraria exigible en los procesos monitorios podría ser de cualquier importe; si bien, anteriormente se exigía una cuantía máxima (5 millones de pesetas). Además, se deberá tener muy presente el régimen general de obligaciones señalado en los artículos 1113,1114 y 1125 del CC $^{53}$.

\section{Documentos acreditativos de la deuda}

Como señala el Prof. Cortés: "El crédito debe estar reflejado en un documento, o en un conjunto de documentos (no necesariamente el documento debe ser sinónimo de papel), que acrediten por sí mismos la existencia del mismo. Son títulos que permiten el inicio del proceso monitorio cualquier documento, independientemente de su forma, clase o el soporte físico en que se encuentre, que esté firmado por el deudor, que lleve su sello, impronta o marca, o que lleve cualquier señal de todo tipo, física o electrónica, que provenga del deudor (art. 812.1.1 ${ }^{\circ}$ ). También pueden ser títulos cualquier documento proveniente del acreedor, que refleje la deuda, siempre y cuando sean documentos que habitualmente se utilicen en el tráfico jurídico para documentar los créditos y las deudas entre las partes de la relación crediticia (art. 812.1.2 ${ }^{\circ}{ }^{54}$ '. Además, el artículo 812.2 LEC recoge como documentos acreditativos de la deuda, aquellos que acrediten una relación anterior duradera $\left(812.2 .1^{\circ}\right)$ y certificaciones de impago de gastos comunes de comunidades de propietarios de bienes inmuebles urbanos $\left(812.2 .2^{\circ}\right)$.

Se trata, en definitiva, de que el acreedor aporte una apariencia de buen derecho sobre la existencia y caracteres de la deuda que reclama, de manera que cualquier documento usualmente empleado en transacciones comerciales puede ser un instrumento válido de prueba de la relación crediticia ${ }^{55}$. Incluso debe aceptarse el valor probatorio de las fotocopias de acuerdo con el art. 268.2 LEC, siempre que no sean discutidas por la otra parte ${ }^{56}$.

En relación a los documentos señalados en el art 812 LEC, el profesor Cubillo observa que no son tratados por igual los cuatro grupos de documentos enumerados, así en los dos primeros grupos (documentos de cualquier tipo firmados por el deudor y facturas, albaranes y otros documentos habituales en el comercio) el juzgador deberá valorar la suficiencia o no del documento para acreditar la deuda. Por el contrario, en los dos últimos grupos (documentos habituales en el comercio de tracto sucesivo, así como verificaciones de impago de gastos comunes en comunidades de propietarios) la ley estima que ya son suficientes por sí mismos de manera que no será preciso tal juicio de suficiencia, al admitir a trámite la solicitud de monitorio ${ }^{57}$.

\section{Solicitud}

\footnotetext{
52 PLANCHADELL GARGALLO, A., La tutela del crédito..., op. cit., p. 65.

${ }^{53}$ BERMÚDEZ REQUENA, J.M., Proceso monitorio ..., op. cit., p. 73.

${ }^{54}$ CORTÉS DOMÍNGUEZ, V. y MORENO CATENA, V., Derecho procesal civil., op. cit., p. 187.

${ }^{55}$ IBARRA SÁNCHEZ, J.L., Aspectos fundamentales del procedimiento ..., op. cit., p. 66.

${ }^{56}$ Ibidem, p. 78.

${ }^{57}$ PEITEADO MARISCAL, P. y CUBILLO LÓPEZ, I., Instrumentos procesales..., op. cit., p. 118.
} 
El proceso se inicia mediante solicitud dirigida al tribunal del domicilio del deudor, que no es estrictamente una demanda ya que carece de relato de hechos y fundamentos jurídicos, e incluso puede rellenarse formulariamente en los juzgados. Este escrito de solicitud deberá contener los siguientes datos: identidad y domicilio del acreedor, identidad y domicilio del deudor, origen y cuantía de la deuda, así como documentos acreditativos de la misma. El escrito finalizará con la pretensión del requerimiento de pago al deudor (arts. 814 y 815 LEC).

Por lo que se refiere a la postulación, no será necesaria la asistencia de abogado y procurador, con independencia de la cuantía reclamada, sin que esto suponga una merma de los derechos de defensa del deudor ${ }^{58}$. No obstante, si el deudor plantea oposición, el procedimiento se transformará en juicio declarativo $\mathrm{y}$, en consecuencia, será preceptiva la intervención de abogado y procurador cuando se reclamen más de 2.000 euros, siguiendo las reglas generales (arts. 23 y 31 LEC). A su vez, la petición inicial del monitorio estará condicionada al pago de la tasa judicial siempre que se supere la cantidad de 2.000 euros, mientras que en cantidades inferiores el acreedor estará liberado del pago de la misma ${ }^{59}$.

En la doctrina se plantea la problemática acerca de si son o no admisibles las peticiones de medidas cautelares que acompañen al escrito de solicitud del proceso monitorio. El Consejo General del Poder Judicial, en adelante CGPJ, considera que la celeridad y la breve tramitación del monitorio dificultan el periculum in mora necesario para la adopción de medidas cautelares y, por otro lado, dificultan garantizar la contradicción que exige el artículo 733 LEC. En cambio, Bermúdez entiende que no admitir la petición de medidas cautelares en el monitorio supone un agravio comparativo respecto a la posición del demandante en los procesos declarativos y que nada obsta la posibilidad de acompañar una cláusula al escrito monitorio de solicitud de medidas cautelares para el caso de que el deudor se oponga ${ }^{60}$. Creo que la posición del CGPJ es la más acertada al respecto, ya que la finalidad de la medida cautelar es asegurar la efectividad de la tutela judicial que pudiera otorgarse en la sentencia estimatoria (artículo 721 LEC) y que, en virtud del artículo 728 de la misma ley, solo podrán acordarse si, quien las solicita justifica que durante la pendencia del proceso podrían producirse situaciones que impidieren o dificultaren la efectividad de la tutela mencionada anteriormente. Dichas situaciones son bastantes improbables dada la celeridad que caracteriza al proceso monitorio.

\section{Admisión a trámite}

La admisión a trámite aparece regulada en el artículo 815.1 LEC, que establece: "Si los documentos aportados con la petición fueran de los previstos en el apartado 2 del artículo 812 o constituyeren un principio de prueba del derecho del peticionario, confirmado por lo que se exponga en aquella, el secretario judicial requerirá al deudor para que, en el plazo de 20 días pague al peticionario, acreditándolo ante el tribunal, o comparezca ante este y alegue de forma fundada y motivada, en escrito de oposición, las razones por las que, a su entender, no debe, en todo o en parte, la cantidad reclamada. En caso contrario dará cuenta al juez para que resuelva lo que corresponda sobre la admisión a trámite de la petición inicial”.

\footnotetext{
${ }^{58}$ STS 12-9-2005 RJ/715877.

${ }^{59}$ PEITEADO MARISCAL, P. y CUBILLO LÓPEZ, I., Instrumentos procesales..., op. cit., p. 118.

${ }^{60}$ BERMÚDEZ REQUENA, J.M., Proceso monitorio..., op. cit., pp. 114-115.
} 
Como puede apreciarse, el LAJ se encargará de examinar si la petición monitoria cumple los presupuestos procesales exigidos y si, además, se acompaña de los documentos previstos en la ley y que puedan constituir un principio de prueba. No se trata de un juicio explícito del LAJ sino implícito, esto es, si finalmente la petición es admitida a trámite será porque se considera que cumple con los presupuestos señalados en el artículo $815^{61}$.

En este sentido, se puede hablar de un control genérico procesal y un control específico o documental: el primero recaerá sobre la identidad, capacidad jurídica y procesal, representación de las partes, competencia objetiva, domicilio del deudor y naturaleza de la deuda exigida; el segundo, se realiza sobre los documentos que el acreedor ha de presentar, si son los exigidos en la LEC o cualesquiera otros que puedan suponer una apariencia de buen derecho respecto de la pretensión del acreedor ${ }^{62}$. En este control que lleva a cabo el LAJ se puede comprobar la naturaleza documental del procedimiento, tal y como establece el artículo 812 LEC.

Sin embargo, la práctica de los tribunales parece haber malinterpretado el control documental que corresponde al LAJ y excediéndose en su función garantista, muchas veces más que un control de apariencia de buen derecho realiza un auténtico examen probatorio desvirtuándose la naturaleza del monitorio y acercándolo al proceso ordinario. De ello da buena prueba el alto volumen de inadmisiones a trámite en la estadística judicial de los procesos monitorios alcanzando casi un $47 \%$ de las peticiones iniciales $^{63}$. Lo cierto es que la reforma del año 2009, que atribuyó estas competencias de control al LAJ, ha supuesto un enorme aumento estadístico de los decretos, llegando al $175 \%$ de incremento ${ }^{64}$.

La ley 4/2011, de 24 de marzo, de modificación de la ley 1/2000, de 7 de enero, de Enjuiciamiento Civil, para facilitar la aplicación en España de los procesos monitorio europeo y de escasa cuantía, modificó el apartado 3 del artículo 815 permitiendo al LAJ, a la luz de la documentación aportada, proponer al juez la reducción de la cuantía señalada en la petición. El juez, dará traslado al acreedor para que en el plazo de 10 días acepte dicha reducción o se oponga. Si transcurrido el mismo no hay respuesta del acreedor se archivará el proceso monitorio ${ }^{65}$. Esto ha supuesto una importante modificación respecto a la legislación anterior, y lo cierto es que se sobrepasa el mero control ejercido sobre la naturaleza de la deuda reclamada y su existencia a través de aportación de un principio de prueba para ir más allá, como si de un procedimiento declarativo se tratara ${ }^{66}$.

\footnotetext{
${ }^{61}$ PEITEADO MARISCAL, P. y CUBILLO LÓPEZ, I., Instrumentos procesales..., op. cit., p. 120.

${ }^{62}$ IBARRA SÁNCHEZ, J.L., Aspectos fundamentales del procedimiento ..., op. cit., p. 137.

${ }^{63}$ Ibidem, pp. 138-141.

${ }^{64}$ LARA HERNÁNDEZ, R., "Sin la toga", Revista actualidad jurídica Aranzadi, n. 907, (2015), p. 16.

"Los procesos monitorios desde que están en manos de los secretarios judiciales se resuelven en mayor número y más rápido se ha pasado de una pendencia de unos 422.000 en 2008 a sólo 317.000 en 2013. Si tomamos como muestra el monitorio, que son un $50 \%$ de los asuntos que entran en los juzgados de lo civil, significa que estamos devolviendo a la economía de la gente miles de millones de euros paralizados".

${ }^{65}$ PLANCHADELL GARGALLO, A., La tutela del crédito..., op. cit., p. 118.

${ }^{66}$ IBARRA SÁNCHEZ, J.L., Aspectos fundamentales del procedimiento..., op. cit., pp. 142-143.
} 
La admisión a trámite se realizará mediante decreto del LAJ. Teóricamente, nada impide que contra este decreto se pueda interponer recurso de reposición ante el mismo LAJ (artículo 451.1 LEC); si bien, dada la naturaleza del proceso monitorio supondría complicar y retrasar la rápida tramitación de este procedimiento ${ }^{67}$. La inadmisión se acordará mediante auto del juez que podrá ser recurrido en apelación, no obstante, la resolución de este recurso será lenta y puede frustrar las expectativas del acreedor; por ello, en la práctica hay quien aconseja volver a interponer ante otro juzgado la petición monitoria, o bien, iniciar un proceso declarativo ${ }^{68}$.

\section{CONTROL JUDICIAL DE LAS CLÁUSULAS ABUSIVAS}

\section{Las condiciones generales de la contratación}

En el preámbulo de la Ley sobre Condiciones Generales de la Contratación, en adelante LCGC, se dice que una condición general es una cláusula que está predispuesta e incorporada a una pluralidad de contratos exclusivamente por una de las partes. A continuación, el art. 1.1 de la LCGC define las condiciones generales como: "las cláusulas predispuestas, cuya incorporación al contrato sea impuesta por una de las partes, con independencia de la autoría material de las mismas, de su apariencia externa, de su extensión y de cualesquiera otras circunstancias, habiendo sido redactadas con la finalidad de ser incorporadas a una pluralidad de contratos".

La Ley General para la Defensa de los Consumidores y Usuarios, en adelante, LGDCU, no contiene una definición de condiciones generales, limitándose a decir de ellas que son las cláusulas no negociadas individualmente. Se trata de un concepto más amplio que el de la LCGC puesto que no se exige que hayan sido redactadas para ser aplicadas a una pluralidad de acuerdos. Por ello, se cree necesario ofrecer una definición más exhaustiva acerca de lo que ha de entenderse como condiciones generales de la contratación. En este sentido, Pazos Castro, las define como: "el conjunto de cláusulas mediante las cuales una persona, que normalmente reúne la condición de empresario y que no tiene que ser quien las ha redactado efectivamente, configura el contenido contractual básico de una pluralidad, determinada o indeterminada, de negocios jurídicos patrimoniales futuros, imponiendo tales cláusulas de modo que, como regla general, no aceptará una modificación de las mismas"69. Esta definición recoge las cuatro notas características por las que identificarlas, estas son: a) contractualidad, por lo que se entiende que su formulación responda al deseo del predisponente de incorporarlas a un contrato, b) predisposición, que consiste en que la concepción de las condiciones contractuales tenga lugar de manera anticipada, c) imposición, para indicar que el predisponente no está dispuesto a contratar si no se aplican al negocio todas y cada una de las condiciones previamente formuladas, y d) generalidad, que se refiere al hecho de que estas cláusulas tengan como finalidad incorporarse a una pluralidad de contratos que celebre el predisponente en el desarrollo de su actividad económica ${ }^{70}$.

\section{El control de oficio}

\footnotetext{
${ }^{67}$ PLANCHADELL GARGALLO, A., La tutela del crédito..., op. cit., p. 118.

${ }^{68}$ IBARRA SÁNCHEZ, J.L., Aspectos fundamentales del procedimiento ..., op. cit., p. 141.

69 PAZOS CASTRO, R., El control de las cláusulas abusivas en los contratos con consumidores, Aranzadi, 2017, Pamplona, p. 78.

${ }^{70}$ Ibidem, pp. 80-93.
} 
Antes de efectuar el requerimiento de pago puede ser necesaria la intervención del juez, si es que la deuda reclamada tiene como base un contrato entre un empresario o profesional y consumidor o usuario. En estos supuestos, el art. 815.4 LEC introducido tras la reforma de la Ley 42/2015, impone el preceptivo control judicial y ex oficio de cualquier cláusula que constituya el fundamento de la petición monitoria o que determine la cantidad exigible. Si el juez apreciase que alguna de estas cláusulas pudiera ser abusiva, oirá por cinco días a las partes pronunciándose después sobre el carácter abusivo o no de las mismas ${ }^{71}$.

El preámbulo de la Ley 42/2015 revela el motivo por el cual se introdujo este apartado cuarto. Esto es, dar cumplimiento a la sentencia del Tribunal de Justicia de la Unión Europea, en adelante TJUE, de 14 de junio de 2012, en el asunto Banco Español de Crédito; donde, tras el examen del proceso monitorio en España en relación a la Directiva 93/13 de la Comunidad Europea sobre las cláusulas abusivas en los contratos celebrados con consumidores, esta sentencia declaró que la normativa española no era acorde con el Derecho de la Unión en materia de protección de consumidores, puesto que no se permitía al juez el examen del carácter abusivo o no de las condiciones contractuales en las demandas de monitorio ${ }^{72}$.

No obstante, hay quien considera que este control de oficio y contradictorio desnaturaliza el diseño estructural del proceso monitorio en la medida en que queda desprovisto de las notas de rapidez y sencillez que le son propias. En su afán de proteger al deudor, ha llegado a desvirtuar lo poco que quedaba del monitorio tras encomendar buena parte de su tramitación a los LAJ ${ }^{73}$.

Sin embargo, los problemas de compatibilidad de la normativa española con la comunitaria no terminaron con la introducción de este control de oficio porque el TJUE volvió a declarar incompatible la regulación del proceso monitorio español con la mencionada Directiva, en la medida en que no permite al juez que conoce de la ejecución (como consecuencia de la no oposición del deudor) apreciar de oficio el carácter abusivo de una cláusula contractual en materia de consumidores y usuarios ${ }^{74}$. Y esta facultad de apreciación de oficio, con la consiguiente posibilidad de denuncia de parte, se ha introducido - como es sabido- entre las normas que regulan la ejecución de títulos extrajudiciales (arts. 552.1 y 557.1.7 ${ }^{\mathrm{a}}$ LEC).

A pesar de su afán garantista, la reforma de 2015 no ha sido bien acogida por la doctrina procesal y se cuestiona su utilidad, su coherencia con la naturaleza del procedimiento monitorio y el carácter o no de cosa juzgada del auto que resuelve sobre la lesividad de la cláusula contractual discutida. Gómez Amigo considera que no era necesaria la introducción del apartado cuarto, ya que en el artículo 815.3 LEC se prevé que el juez controle de oficio la cuantía solicitada en el escrito monitorio y bien se podía haber utilizado este control jurisdiccional como cauce para examinar el carácter abusivo

\footnotetext{
71 OLIVA SANTOS, A., DÍEZ-PICAZO GIMÉNEZ, I. y VEGA TORRES, J., Las especialidades procedimentales de los procesos ordinarios, Curso de Derecho Procesal Civil II. Parte especial, Ramón Areces, 2016, Madrid, p. 563.

72 FRAGA MANDIÁN, A., "Cláusulas abusivas y cosa juzgada”, Proceso Civil, Segundo trimestre, n. 123, (2016), p. 19.

73 OLIVA SANTOS, A., DÍEZ-PICAZO GIMÉNEZ, I. y VEGA TORRES, J., Curso de Derecho Procesal Civil II..., op. cit., p. 564.

${ }^{74}$ STJUE 18-2-2016 (caso Finanmadrid E.F.C., S.A.).
} 
de las condiciones generales discutidas ${ }^{75}$. De otro modo, se contradice la naturaleza del proceso monitorio, puesto que al darle al deudor audiencia en dicho trámite y, además, declarar que el auto resolutorio del incidente es apelable, ciertamente, supone menoscabar la agilidad y eficacia del monitorio, demorando su tramitación ${ }^{76}$.

Finalmente, también se discute si el auto resolutorio de dicho incidente es o no apelable. El preámbulo de la Ley 42/2015 así lo establece; sin embargo, en el articulado de la ley nada se dice al respecto y algún autor ha considerado que es de aplicación la regla general de la LEC que establece el carácter de cosa juzgada de la resolución cuando expresamente no se diga lo contrario (arts. 34, 35, 447, 552.1 y 561.1 LEC). Si no tiene fuerza de cosa juzgada, podría darse la paradójica circunstancia de que el mismo juez que inicialmente se pronuncie sobre la abusividad, habiendo oposición, mude su criterio en la sentencia que ponga término al ulterior procedimiento declarativo ${ }^{77}$. No habría estado de más que el legislador expresamente hubiese indicado si produce o no efecto de cosa juzgada en el texto principal de la ley.

\section{EL REQUERIMIENTO DE PAGO}

\section{Contenido y requisitos legales}

El requerimiento de pago se encuentra regulado en el art. 815 LEC, que establece que, toda vez que se haya comprobado que la documentación del peticionario constituye un principio de prueba de la deuda, el LAJ requerirá al deudor en la forma prevista en el artículo 161, para que en el plazo de 20 días pague al peticionario o comparezca ante el tribunal para mostrar su oposición. López Sánchez considera que es un acto de naturaleza ejecutiva que se adelanta respecto a su momento oportuno para ser utilizado como un acto de notificación al deudor de la admisión de la petición monitoria ${ }^{78}$. Esta naturaleza ejecutiva que aprecia el autor quizás no sea una opinión acertada, en el sentido de que sólo la actitud pasiva del deudor podrá dotar de ejecutividad ese requerimiento de pago; que, por otro lado, solo será efectivo si el acreedor insta el correspondiente proceso ejecutivo.

En opinión de Planchadell, lo fundamental en este punto son los preceptos relativos a la notificación del requerimiento de pago; esto es, que la comunicación se realice en la forma legalmente prevista, puesto que es fundamental para el ejercicio del derecho de defensa del deudor y el cumplimiento del principio de contradicción, ya que, hasta el momento en que es requerido, el deudor teóricamente desconoce la existencia de un proceso en su contra. La relación entre el requerimiento de pago y el derecho a la tutela judicial efectiva es evidente ${ }^{79}$. En el mismo sentido, Ibarra considera que la naturaleza del monitorio como proceso de inversión del contradictorio y el carácter ejecutivo que se atribuye a la actitud pasiva del deudor tienen como presupuesto el conocimiento efectivo y real del requerimiento de pago por el deudor; y por ello, se ha de ser muy estricto con el cumplimiento de las formalidades requeridas en el acto de comunicación $^{80}$. En el requerimiento, el LAJ advertirá al deudor que en caso de no

\footnotetext{
${ }^{75}$ GÓMEZ AMIGO, L., “La evolución del proceso monitorio...”, op. cit., p. 16.

${ }^{76}$ PICÓ I JUNOY, J., "Réquiem por el proceso monitorio”, Justicia, n. 2, (2015), pp. 525-528.

${ }^{77}$ FRAGA MANDIÁN, A., "Cláusulas abusivas y cosa juzgada...”, op. cit., p. 19.

${ }^{78}$ LÓPEZ SÁNCHEZ, J., El proceso monitorio, La ley, 2000, Madrid, p. 199.

${ }^{79}$ PLANCHADELL GARGALLO, A., La tutela del crédito..., op. cit., p. 119.

${ }^{80}$ IBARRA SÁNCHEZ, J.L., Aspectos fundamentales del procedimiento..., op. cit., p. 159.
} 
pagar o no comparecer ante el tribunal, podrá dictarse un auto despachando ejecución por la cantidad reclamada ${ }^{81}$.

Bermúdez Requena define este requerimiento como la orden o mandato judicial, bajo la forma de decreto expedido por el LAJ, que constituye la verdadera esencia del proceso monitorio porque lo que el acreedor persigue es precisamente este mandato u orden judicial de pago, que en el caso de ser desatendida se convierta en título de ejecución. Además, este es un elemento constante en el derecho comparado, pues lo encontramos, en los mismos términos, en el artículo 641 del codice di procedura civile italiano ${ }^{82}$.

La ley no establece el contenido del requerimiento de pago, si bien se sobreentiende que deberá indicarse: el lugar y fecha en el que se emite, el órgano jurisdiccional que lo emite, el proceso en el que se encuadra, una sucinta motivación demostrando que se han examinado los presupuestos del proceso monitorio y la emisión del requerimiento de pago propiamente dicho. En este punto será fundamental que el LAJ exponga al deudor las opciones que se le presentan y las consecuencias jurídicas de su acción en uno u otro sentido ${ }^{83}$.

\section{La notificación del requerimiento}

La notificación del requerimiento se hará en la forma que se encuentra regulada en el artículo 161 LEC, y se sustancia mediante la entrega de la copia del decreto del LAJ requiriendo el pago de la cantidad debida, si bien habrán de tenerse en cuenta las siguientes precisiones:

a) La entrega al destinatario de la comunicación se efectuará de ordinario en el domicilio de la persona que deba ser notificada. La entrega se documentará por medio de diligencia, que será firmada por el funcionario que la practique o, en su caso, por el procurador que la efectúe, así como por la persona requerida. Aunque, como la postulación en el proceso monitorio no es necesaria, será poco frecuente que sea el procurador del acreedor quien lleve a cabo la notificación.

b) Cuando el destinatario de la comunicación sea hallado en el domicilio y se niegue a recibir la copia de la resolución o no quiera firmar la diligencia, se le hará saber que dicha copia queda a su disposición en la oficina judicial, produciéndose los efectos de la comunicación y de todo ello quedará constancia en la diligencia.

c) Si el domicilio donde se pretende practicar la comunicación fuera el lugar en el que el destinatario esté empadronado o sea el domicilio a efectos fiscales, o el que aparezca en registro oficial o publicaciones de colegios profesionales, o fuere la vivienda o local arrendado al deudor, y no se encontrase allí, podrá efectuarse la entrega a cualquier empleado, familiar o persona con la que conviva mayor de 14 años que se encuentre en ese lugar, advirtiéndose al receptor que está obligado a entregar la copia de la resolución al destinatario de ésta, o a darle aviso si conoce su paradero.

\footnotetext{
${ }^{81}$ CORTÉS DOMÍNGUEZ, V. y MORENO CATENA, V., Derecho procesal civil., op. cit., p. 189.

${ }^{82}$ BERMÚDEZ REQUENA, J.M., Proceso monitorio ..., op. cit., p. 123.

${ }^{83}$ PLANCHADELL GARGALLO, A., La tutela del crédito..., op. cit., p. 120.
} 
d) En el caso de que no se halle a nadie en el domicilio al que se acuda para la práctica de un acto de comunicación, el LAJ o funcionario al efecto procurará averiguar si vive allí su destinatario llevando a cabo cuantas averiguaciones o indagaciones sean necesarias para hallar el lugar donde pueda encontrarse el deudor.

e) Finalmente, si no es posible practicar la notificación del requerimiento de pago y no se puede averiguar un nuevo domicilio en el que hallar al deudor, la consecuencia será la terminación del proceso monitorio mediante auto del juez para poner fin al procedimiento (artículo 813.2), y se reservará al acreedor el derecho a instar de nuevo el procedimiento ante el juzgado competente, devolviéndosele la documentación aportada ${ }^{84}$. En todo caso, si con posterioridad al archivo el juzgado conociese un nuevo domicilio del deudor fuera de su partido judicial, no podrá solicitar auxilio judicial mediante exhorto ${ }^{85}$.

\section{Especialidades del requerimiento en propiedad horizontal}

Desde la introducción del monitorio en el año 2000 hasta la reforma de 2009, se discutía la posibilidad de que el requerimiento de pago se efectuase mediante edictos en aquellos casos en los que no hubiese sido posible notificar personalmente al deudor para requerir el pago. La reforma del año 2009 zanjó esta cuestión estableciendo como regla que la notificación sería siempre personal, pero, excepcionalmente, en los casos de deudas que tengan su origen en la LPH, se permitiría la publicación edictal del requerimiento. La comunicación deberá realizarse en el domicilio señalado por el deudor a la comunidad de propietarios; en su defecto, se intentará la comunicación en el piso o local; y si tampoco pudiera hacerse efectiva de este modo, se efectuará mediante comunicación edictal ${ }^{86}$.

El fundamento de esta excepción, según Ibarra Sánchez, se encuentra en la especial relación que existe entre el deudor y el inmueble que ocupa, en el cual tiene o tenía su domicilio y que sería el indicado a efectos de notificaciones en virtud de un contrato de alquiler, o bien en virtud de la obligación de pago de cuotas de la comunidad $^{87}$.

Si bien esta era una cuestión que ya había sido resuelta por la jurisprudencia, considerándose válida la comunicación por edictos, con carácter subsidiario fundándola en el artículo 21 de la LPH y en la obligación de todo propietario de facilitar a la comunidad un domicilio de notificaciones ${ }^{88}$.

Ahora bien, dada la trascendencia que para la tutela judicial efectiva tiene este trámite, obviamente, esta posibilidad de comunicación por medio de edictos tendrá siempre carácter subsidiario y habrán de comprobarse por el tribunal varios presupuestos previos, a saber: deberá acreditarse que la comunidad de propietarios ha intentado requerir de pago extrajudicial y fehacientemente al deudor, que este requerimiento haya sido efectuado en el domicilio facilitado por el deudor a la

\footnotetext{
${ }^{84}$ IBARRA SÁNCHEZ, J.L., Aspectos fundamentales del procedimiento ..., op. cit., p. 162.

${ }^{85}$ Ibidem, p. 164.

86 OLIVA SANTOS, A., DÍEZ-PICAZO GIMÉNEZ, I. y VEGA TORRES, J., Curso de Derecho Procesal Civil II..., op. cit., p. 565.

${ }^{87}$ IBARRA SÁNCHEZ, J.L., Aspectos fundamentales del procedimiento ..., op. cit., p. 161.

${ }^{88}$ BERMÚDEZ REQUENA, J.M., Proceso monitorio..., op. cit., p. 128.
} 
comunidad, y que la petición del monitorio sea dirigida al juzgado en el que se encuentre el domicilio señalado por el deudor en la documentación de la Comunidad; y finalmente, que se hayan intentado y agotado todas las medidas de averiguación judicial del domicilio ${ }^{89}$.

En todo caso, el administrador deberá aportar, junto a la petición inicial del monitorio, la acreditación documental de que al propietario se le practicó la notificación del acuerdo de liquidación de la deuda por el secretario con el visto bueno del presidente de la comunidad. A este respecto, dice el art. 9.1 h) de la LPH que la comunicación debe dirigirse por cualquier medio que permita tener constancia de su recepción, no sólo la comunicación sino también el contenido de esta. Esta notificación extrajudicial deberá colocarse en el tablón de anuncios de la comunidad, o en un lugar visible de uso general habilitado al efecto y que no pueda pasar desapercibido para los miembros de la comunidad, al menos durante un plazo de 3 días ${ }^{90}$.

Una vez presentada la petición inicial del monitorio, no será posible acumular nuevas cuotas vencidas, de acuerdo con el art. 21 de la LPH ya que de este modo se cercenarían las posibilidades de oposición del propietario afectado ante las posibles vicisitudes del proceso de reclamación de deuda e implicaría una inadmisible infracción del derecho de defensa ${ }^{91}$.

\section{EL ESCRITO DE OPOSICIÓN}

\section{Cambios relativos al escrito de oposición}

Uno de los puntos más confusos del proceso monitorio con anterioridad a la reforma introducida por la Ley 42/2015 era el alcance de los motivos de la oposición del deudor; es decir, si se trataba de una oposición genérica sin motivación o si, por el contrario, debería ser específica, indicando los motivos en que se fundamentaba. Otro aspecto polémico en este sentido era si siendo fundada debía ser completa, de manera que no se pudiesen introducir nuevos motivos en el procedimiento ordinario posterior. Todo ello era de especial relevancia en tanto que la oposición pone fin al proceso monitorio y abre el juicio declarativo, frustrando toda expectativa de celeridad y de eficacia que sustenta este proceso $^{92}$.

Una línea jurisprudencial (SAP de León núm. 248/2015 de 14 de octubre, SAP de Madrid núm. 321/2012 de 10 de diciembre, SAP de Huelva núm. 131/2009 de 21 mayo y núm 201/2008 de 16 de septiembre) en sintonía con los países de nuestro entorno, sostenía que al deudor le bastaba con alegar sucintamente las razones de su oposición sin que estuviese obligado a fundamentar su escrito, lo que podría realizar en el juicio declarativo posterior al contestar la demanda. De hecho, es frecuente encontrar en la práctica la siguiente fórmula: "Disconforme con el correlativo de la demanda. Entiende mi mandante que, a la vista de lo reclamado de contrario, la expresa cantidad en absoluto resulta acogerse a lo dispuesto en lo previsto en el artículo 812 LEC"93.

\footnotetext{
${ }^{89}$ Idem.

90 AAVV., Cuestiones prácticas sobre propiedad horizontal. Memento experto, Francis Lefevbre, 2014, Madrid, p. 221.

91 Ibidem, p. 228. SAP Alicante, 2-3-2012, EDJ 32690.

92 IBARRA SÁNCHEZ, J.L., Aspectos fundamentales del procedimiento..., op. cit., pp. 179-180.

${ }^{93}$ Ibidem, p. 182.
} 
Otra jurisprudencia (SAP de Oviedo núm. 275/2015 de 14 de octubre y SAP Gijón núm. 245/2015 de 13 de octubre) señalaba que la oposición sí que debía justificarse, por exigencia legal y por imposición de los principios de buena fe y lealtad procesal (art. 11 LOPJ y art. 247 LEC). De modo que algunas resoluciones judiciales directamente inadmitían la oposición fundada simplemente en la expresión "me opongo porque no debo nada" 94 .

Frente a esta divergencia de criterios, la tesis más acertada parecía ser la de Picó I Junoy, quien consideraba que la justa reciprocidad del tratamiento procesal de ambas partes parece imponer que el demandado debía dar algún motivo para oponerse pero no todas las razones de su negativa a pagar; al igual que el acreedor cuando formula su escrito de petición monitoria no está obligado a fundamentar exhaustivamente su petición ${ }^{95}$.

Un problema añadido era determinar el grado de vinculación de las partes a sus escritos de oposición o solicitud dentro del proceso monitorio en el declarativo posterior. En los juicios verbales, tanto el acreedor como el deudor podían ampliar la fundamentación de su pretensión en la vista. Pero en el juicio ordinario, formulada la oposición, el acreedor debía interponer demanda en el plazo de un mes sin estar vinculado al escrito de solicitud monitoria ${ }^{96}$. La situación se transformó con la Ley 42/2015, puesto que exige al deudor un plus en la motivación de su escrito de oposición: ya no es suficiente que argumente sucintamente, sino que el legislador le obliga a que alegue de forma fundada y motivada, en escrito de oposición, las razones por las que no debe, en todo o en parte, la cantidad reclamada. La denominada oposición meramente formal o inmotivada se entenderá equivalente a la falta de oposición del deudor y convertirá en título ejecutivo el requerimiento de pago ${ }^{97}$. Gómez Amigo, en cambio, considera que cualquier oposición que se presente, sea más o menos escueta, o más o menos fundada, debe dar lugar a la terminación del monitorio y su continuación como juicio verbal. Sólo el incumplimiento radical de la norma, asimilable a la falta de oposición, permitiría su inadmisión ${ }^{98}$.

También ha quedado resuelto el problema de la vinculación del deudor a su escrito de oposición, al menos en el caso del juicio verbal, puesto que, tras la reforma del mismo (arts. 437 y 438 LEC), el escrito de oposición va a ser el único momento procesal que tenga el deudor para presentar sus alegaciones justificando su negativa al requerimiento de pago, como veremos un poco más adelante (art. 818.2 LEC). De modo que, si en el trámite de fijación de los hechos del artículo 443 LEC, intentara introducir otros distintos a los alegados en el escrito de oposición, sería intocable la prohibición de cambio del objeto del proceso del artículo 412 LEC $^{99}$. Por esta razón, piensa Bonet Navarro que la reforma al introducir la contestación escrita promueve la igualdad de

\footnotetext{
${ }^{94}$ Ibidem, pp. 183-185.

95 PICÓ I JUNOY, J., "Nuevas perspectivas sobre la debida armonización del proceso monitorio y el posterior juicio ordinario", Revista Justicia, n.1, (2013), p. 73.

${ }^{96}$ IBARRA SÁNCHEZ, J.L., Aspectos fundamentales del procedimiento ..., op. cit., p. 188.

${ }^{97}$ BERMÚDEZ REQUENA, J.M., Proceso monitorio..., op. cit., pp. 132-134.

${ }^{98}$ GÓMEZ AMIGO, L., "La evolución del proceso monitorio..., op. cit., p. 22.

${ }^{99}$ Ibidem, p. 142.
} 
armas y la necesaria información de las partes, facilitando el ejercicio del derecho de defensa ${ }^{100}$.

\section{Contenido del escrito de oposición}

Una de las cuestiones más debatidas es cuál debe ser el contenido de la oposición, es decir, cuáles son los motivos por los que el deudor se opone. Al respecto existen dos claras tendencias doctrinales: a) Plantear esta oposición por todo tipo de motivos, de fondo y forma, que posteriormente serán discutidos en el proceso ordinario (Correa Delcasso, Gómez Amigo, Quílez Moreno, Picó I Junoy, entre otros); b) posibilidad de limitar los motivos de oposición a criterios únicamente materiales, porque el pago ya se haya realizado, o bien, para exponer las razones por las que este no procede (Hurtado Yelo) ${ }^{101}$.

Respecto al fondo del asunto, podrá alegarse el cumplimiento de la obligación, la condonación de la misma, la confusión de derechos, la compensación, la novación y también la pluspetición. También podrán discutirse los presupuestos del proceso, por ejemplo, el carácter dinerario o líquido de la deuda. Si se alegan cuestiones de carácter procesal podrá centrarse esta oposición en la competencia del tribunal, el cumplimiento de los plazos u otras formalidades procesales ${ }^{102}$.

En cuanto al requisito de motivación, tras la reforma llevada a cabo por la Ley 42/2015, parece que la posición común en la doctrina es la de exigir una motivación sucinta pero suficiente para fundamentar la oposición. No cabría una oposición genérica, como tampoco una fundamentación exhaustiva de los motivos de la oposición el deudor. Esta posición se sustenta sobre el principio de simetría de las partes. En este sentido, al igual que al acreedor no se le exige una fundamentación rigurosa de la petición monitoria tampoco sería justo exigírsela al deudor ${ }^{103}$.

\section{La reconvención}

La reconvención es la conducta del demandado consistente en no limitarse a pedir su propia absolución, sino pedir la concesión de una nueva tutela jurisdiccional frente al actor. A través de la reconvención, las posiciones procesales iniciales se invierten: el demandado pasa ser también demandante $\mathrm{y}$, el demandante será también demandado. En consecuencia, la reconvención supone una ampliación del objeto del proceso pues, aparecerá una nueva acción, esto es, la incoada por el demandado ${ }^{104}$.

Antes de la reforma efectuada por la Ley 42/2015, no era posible reconvenir pues el escrito de oposición no era una contestación a la demanda. La reconvención habría de hacerse después, en los cinco días posteriores a la vista para el caso del juicio verbal, o en el plazo para contestar a la demanda en el caso del juicio ordinario. No obstante, tras la reforma se plantea la cuestión de si el escrito de oposición se trata de

\footnotetext{
100 BONET NAVARRO, J., "Monitorio y juicio verbal para sustanciar la oposición conforme a la ley 42/2015 de 5 de octubre", Diario la Ley, n. 8810, (2016), p. 2.

${ }^{101}$ PLANCHADELL GARGALLO, A., La tutela del crédito..., op. cit., pp. 133-134.

102 Ibidem, p. 134.

${ }^{103}$ Ibidem, p. 140.

104 OLIVA SANTOS, A., DÍEZ-PICAZO GIMÉNEZ, I. y VEGA TORRES, J., Curso de Derecho Procesal Civil II..., op. cit., p. 82.
} 
una contestación a la demanda $\mathrm{y}$, por tanto, sería entonces el momento procesal oportuno para formular la reconvención.

En el caso del juicio ordinario no se plantea este problema, puesto que la reconvención se formulará mediante el trámite de contestación a la demanda, siguiendo las reglas generales, en el nuevo proceso declarativo que se abra (arts. 400, 406 y 407 LEC). La situación cambia en el caso del juicio verbal, pues una lectura conjunta de los artículos 818.2 y 438.2 LEC permite plantear la reconvención al deudor mediante el escrito de oposición, al entender éste como el trámite en el que el deudor contesta a la pretensión formulada contra él, siempre que esta pretensión sea procedente por los cauces del juicio verbal y exista conexión entre ella y las pretensiones del acreedor que figuren en la petición monitoria ${ }^{105}$.

\section{EL JUICIO DECLARATIVO}

\section{Relación entre el proceso monitorio y el posterior juicio declarativo}

Formalizada la oposición por el deudor, el proceso monitorio se va a transformar en un proceso declarativo ordinario; y en este sentido, se pueden dar diversos supuestos: a) que la cuantía del proceso sea superior a $6.000 €$ y el monitorio se transforme en un juicio ordinario; y b) que la cuantía del proceso sea inferior a $6.000 € \mathrm{y}$ proceda su transformación a juicio verbal — con las especialidades del mismo tras la reforma del año 2015-.

La primera cuestión que se ha de resolver en este apartado es si el nuevo proceso declarativo que se abre tras la oposición del deudor se trata del mismo proceso o bien de otro proceso diferente; porque, si se trata de un proceso nuevo, habrá una independencia entre uno y otro. Sin embargo, si el proceso ordinario se tratase de una continuación del monitorio, habrá de determinarse cuál es el grado de vinculación entre ambos $^{106}$. En este sentido, tanto Ibarra como Planchadell consideran que el declarativo posterior es sustancialmente otro juicio, en el que incluso cabría formular nuevas alegaciones y presentar nuevos documentos ${ }^{107}$.

En cambio, Bermúdez Requena considera que sí existe una vinculación entre el monitorio y el ordinario en todos los casos por imperativo de los principios de seguridad jurídica, buena fe procesal y contradicción y defensa del acreedor ${ }^{108}$. Se considera que el problema tiene una más fácil solución si atendemos a las especialidades de cada procedimiento ordinario, por lo que a continuación se detallará la problemática de la vinculación entre monitorio y ordinario en los diversos supuestos procesales que puedan plantearse.

\section{La transformación en juicio ordinario}

En aquellos supuestos en los que la cuantía supere los $6.000 €$, por imperativo legal, tras el decreto del LAJ dando por terminado el proceso monitorio, se otorgará un plazo de un mes al acreedor para que interponga demanda. Transcurrido el cual, si no se

\footnotetext{
105 BERMÚDEZ REQUENA, J.M., Proceso monitorio ..., op. cit., p. 147.

${ }^{106}$ IBARRA SÁNCHEZ, J.L., Aspectos fundamentales del procedimiento ..., op. cit., p. 199.

${ }^{107}$ PLANCHADELL GARGALLO, A., La tutela del crédito..., op. cit., p. 147.

${ }^{108}$ BERMÚdEZ REQUENA, J.M., Proceso monitorio..., op. cit., p. 134.
} 
presentase demanda se sobreseerá el procedimiento ordinario y el acreedor será condenado en costas (art. 818.1 LEC). Este hecho es considerado por Bermúdez Requena como una verdadera carga procesal, que revela la vinculación existente entre el monitorio y el ordinario ${ }^{109}$. En cambio, la mayor parte de los autores consideran que no existe propiamente una dependencia entre ambos procedimientos puesto que tanto el acreedor en su demanda como el deudor en la contestación a la misma podrán introducir nuevos datos y documentos ${ }^{110}$.

Otra cuestión que resolver es si el acreedor podrá incorporar nuevas pretensiones en la demanda de juicio ordinario, o qué ocurriría si presentase su demanda transcurrido el mes concedido para ello. Ciertamente, estos supuestos no tendrían ninguna consideración problemática si se acepta que se trata de procedimientos independientes del monitorio inicial. En estos casos, sencillamente se está en presencia de un nuevo procedimiento y tanto el actor como el demandado tendrán todas sus posibilidades de defensa garantizadas en la demanda y contestación a la misma. No obstante, una posición minoritaria considera que, por imperativo del principio de buena fe procesal y por la prohibición de la mutación del objeto del proceso, el acreedor no podría formular nuevas pretensiones ni aducir nuevas razones a las incorporadas en la petición monitoria y en la impugnación al escrito de oposición ${ }^{111}$.

A pesar de esta posición minoritaria, se juzga más acertada la posición doctrinal que considera que el proceso monitorio español se trata de un modelo mixto y que, una vez terminado el monitorio, se abre un nuevo procedimiento ordinario con todas sus garantías y trámites procesales sin que exista una relación de continuidad o necesidad entre ellos ${ }^{112}$. Textualmente, afirma la profesora Planchadell: "si finalmente el acreedor opta por continuar con su reclamación, incoa un proceso completamente nuevo, de carácter ordinario y plenario, en el que la cuestión litigiosa puede ser debatida en toda su extensión y al que le son aplicables todas las normas que la LEC prevé para el juicio ordinario ${ }^{113}$ ". Personalmente, comparto la opinión de Planchadell, y considero que el proceso declarativo ordinario se trata de un procedimiento nuevo, en el que podrán hacerse valer nuevas pretensiones (sin desvincularse del objeto del proceso monitorio inicial) así como formalizar nuevas alegaciones; puesto que tendrán el correspondiente trámite de audiencia, tanto acreedor como deudor. Quizá sea problemática esta cuestión en cuanto a los juicios verbales en los que no se celebre vista, ya que el deudor quedará vinculado a su escrito de oposición y alegar nuevos hechos sería imposible para el mismo.

\section{La transformación en juicio verbal}

Cuando la cuantía del objeto del proceso es inferior a $6.000 €$, o bien se reclamen rentas o cantidades debidas por el arrendatario de finca urbana, el monitorio se transformará en un juicio verbal y habrán de tenerse en consideración, especialmente, las novedades introducidas por la reforma del año 2015 en este procedimiento. Efectivamente, esta reforma limita la celebración de la vista ante el juez solo los

\footnotetext{
109 Ibidem, p. 138.

110 PEREZAGUA HERRERO, J., "5 preguntas sobre la transformación del monitorio", Revista General de Derecho Procesal, n. 45, (2018), p. 37.

${ }^{111}$ BERMÚDEZ REQUENA, J.M., Proceso monitorio ..., op. cit., p. 139.

112 PLANCHADELL GARGALLO, A., La tutela del crédito..., op. cit., pp. 144-145.

113 Ibidem, p. 146.
} 
supuestos en los que las partes así lo soliciten, o bien cuando el juez lo considere necesario para la dilucidación de los hechos controvertidos (art. 818.2 LEC).

Así, formulada oposición en un proceso monitorio relativo a una deuda inferior a 6.000 euros, el LAJ dará traslado al acreedor para que en el plazo de 10 días pueda impugnar este escrito de oposición y acto seguido decretará el archivo de las actuaciones y su paso a juicio ordinario. Por ello, algunos autores como Ibarra Sánchez consideran que ya no puede entenderse que exista un juicio verbal distinto del procedimiento monitorio y que, tras la reforma, se da una auténtica relación de continuidad entre ambos procedimientos ${ }^{114}$.

En estos casos, como afirma Herrero Perezagua, la oposición del deudor en el monitorio equivale a la contestación a la demanda $\mathrm{y}$, salvo que se celebre vista, el deudor quedará vinculado a este escrito de oposición en el procedimiento verbal sin posibilidad de introducir nuevas razones o aportar nuevos documentos a su pretensión. De este modo, se hace aún más necesario para el deudor una adecuada fundamentación jurídica de su oposición pues, de lo contrario, se verá considerablemente perjudicado en el verbal posterior ${ }^{115}$. Bermúdez Requena, por su parte, considera que la oposición del deudor tendrá la consideración de demanda que principiará el juicio verbal y que, por tanto, se están invirtiendo los roles procesales ${ }^{116}$.

Sin considerar del todo acertada la opinión de Bermúdez Requena, lo cierto es que, de no celebrarse vista, el escrito de oposición principiará el juicio verbal y el escrito de impugnación del acreedor puede ser asimilable a la contestación a la demanda. Ahora bien, no es menos cierto que el escrito de oposición no constituye propiamente una petición sino más bien la refutación a la petición incluida en la solicitud del monitorio. Por ello, se considera más certera la visión de Herrero Perezagua, planteándose por otro lado el problema de la incidencia del escrito de impugnación del acreedor en la lógica procesal tradicional, cuestión esta que se tratará más adelante.

Cuando se celebre vista, porque así lo hayan pedido las partes o porque así lo haya impuesto el juez, acreedor y deudor podrán formular sus observaciones. La novedad introducida por la ley 42/2015, es el artículo 442 en virtud del cual, si el actor no asiste a la vista se le tendrá por desistido y además se le condenará en costas; de otro modo, si es el deudor el que no comparece sencillamente continuará el juicio sin que haya declaración de rebeldía ${ }^{117}$.

Ahora bien, sin duda, los mayores problemas desde el punto de vista procesal se plantean cuando no se celebra vista ante juez, llegándose a cuestionar la simetría de las partes y el principio de seguridad jurídica procesal. En este caso, como señala Bonet, el problema de enlazar dos procedimientos formalmente autónomos se solventa mediante la vinculación del deudor al escrito de oposición en el juicio verbal;

\footnotetext{
114 IBARRA SÁNCHEZ, J.L., Aspectos fundamentales del procedimiento ..., op. cit., p. 205.

115 PEREZAGUA HERRERO, J., "5 preguntas sobre...", op. cit., p. 39.

${ }^{116}$ BERMÚDEZ REQUENA, J.M., Proceso monitorio ..., op. cit., p. 144.

${ }^{117}$ IBARRA SÁNCHEZ, J.L., Aspectos fundamentales del procedimiento ..., op. cit., p. 213.
} 
conjugándose el carácter finalizador del monitorio con una función iniciadora del proceso verbal ${ }^{118}$.

\section{La asimetría de las partes en el juicio verbal}

A pesar de que la regla general será la celebración de una vista previa ante el juez, habrá ocasiones en que dicha vista no se celebre -porque no ha sido pedida por las partes, ni considerada oportuna por el juez- y el proceso verbal se sustancie por una vía exclusivamente documental sobre la base del escrito de oposición y el posterior de impugnación a cargo del acreedor. En estos supuestos concretos la doctrina se cuestiona la lógica garantista del proceso ordinario verbal, pues podría aducirse una situación asimétrica entre las partes que afectaría a su derecho de defensa.

En este sentido, López Amigo y Perezagua consideran que el acreedor tiene dos momentos procesales para mejorar o desarrollar su petición - petición monitoria e impugnación - mientras que el deudor solo contaría con el escrito de oposición para hacer valer su derecho. Este panorama, a su juicio, desemboca en una situación de desigualdad entre las partes y contraviene el elemental principio de seguridad jurídica puesto que, el acreedor puede aprovechar el escrito de impugnación no solo para contradecir los argumentos del deudor sino también para introducir nuevos documentos y pretensiones ${ }^{119}$.

En otro sentido, Ibarra Sánchez observa esta situación no tanto como un peligro para el derecho de defensa de las partes sino como una consecuencia del mantenimiento de la lógica propia del monitorio trasladada ahora al juicio verbal. Más aún, entiende este autor que implícitamente se está introduciendo el monitorio documental cuando la regla general es el modelo mixto. Todo ello, sin duda, se justifica en razón de acelerar el procedimiento para la satisfacción del crédito privilegiando al acreedor $^{120}$.

Planchadell, en una línea más garantista considera que debe atenderse caso a caso la posibilidad de que se genere indefensión en cualquiera de las partes, de modo que se deben limitar los motivos de oposición o bien, de impugnación a la misma, cuando puedan resultar sorpresivos o amenacen la buena fe procesal sobre todo en el juicio verbal ${ }^{121}$.

Finalmente, Bermúdez Requena afirma que la reforma del juicio verbal introducida por la ley $42 / 2015$, en este caso vulnera el principio de buena fe procesal y genera indefensión en el deudor por los motivos ya indicados. Este autor propone, para equilibrar la posición de las partes, eliminar el trámite de impugnación y conceder un plazo de tres días para la solicitud de vista; en el caso de que no se solicite, podrá directamente el juez dictar sentencia sobre el asunto ${ }^{122}$.

\footnotetext{
118 BONET NAVARRO, J., "La relativa autonomía del juicio que corresponda tras la oposición en los procedimientos monitorios", Problemas actuales del proceso iberoamericano, I., Actas, Málaga, 2006, pp. 373-386.

${ }^{119}$ GÓMEZ AMIGO, L., "La evolución del proceso monitorio..., op. cit., pp. 22-23. Vid. PEREZAGUA HERRERO, J., "5 preguntas sobre...”, op. cit., pp. 35-40.

${ }^{120}$ IBARRA SÁNCHEZ, J.L., Aspectos fundamentales del procedimiento ..., op. cit., p. 206.

${ }^{121}$ PLANCHADELL GARGALLO, A., La tutela del crédito..., op. cit., p. 160.

122 BERMÚDEZ REQUENA, J.M., Proceso monitorio ..., op. cit., p. 146.
} 


\section{LA EJECUCIÓN}

Existe un proceso de ejecución ordinario único, que puede ser de título judicial o extrajudicial; y cuando es de título judicial, puede ser relativo a una condena dineraria o no dineraria. La ejecución de título extrajudicial es siempre dineraria. Y luego hay especialidades procesales para los casos de las ejecuciones sobre bienes hipotecados o pignorados. Así, por ejemplo, se encuentran la ejecución dineraria (arts. 571 a 680 LEC), la ejecución de bienes hipotecados o pignorados (arts. 681 a 698 LEC), la ejecución por obligaciones de entregar cosas (arts. 701 a 704), la ejecución por obligaciones de hacer o no hacer (arts. 705 a 711 LEC) y la ejecución por la liquidación de daños y perjuicios, frutos y rentas y rendición de rentas (arts. 712 a 720 LEC) ${ }^{123}$. Dentro de este elenco de procesos de ejecución, la derivada del proceso monitorio ha de encuadrarse en los procesos de ejecución dineraria.

El artículo 117.3 de la Constitución Española, en adelante CE, establece que el ejercicio de la potestad jurisdiccional consiste tanto en juzgar como en ejecutar lo juzgado y, con ello, se alude a las dos funciones básicas de los tribunales. La primera, declarar o decir el derecho que corresponde (proceso de declaración) y la segunda, ejecutar lo juzgado (proceso de ejecución). Sin embargo, no siempre el proceso ejecutivo viene precedido de una declaración previa de los tribunales; por ello, hay que distinguir entre ejecuciones con declaración y ejecuciones sin declaración. La ejecución con declaración es necesaria cuando hay una sentencia estimatoria de una pretensión de condena, entonces, la tutela judicial efectiva no se logra con la mera declaración del derecho, sino que exige la efectividad fáctica de dicha sentencia; esto es, su cumplimiento, voluntario o forzoso. La ejecución sin declaración se produce en aquellos casos en los que el legislador permite iniciar el proceso de ejecución sin que exista declaración judicial previa, atribuyendo fuerza ejecutiva a documentos que provienen de negocios jurídicos realizados por las partes constituyendo así un privilegio procesal ${ }^{124}$.

La ejecución monitoria, como se ha mencionado, se trata de un proceso de ejecución dineraria precedida de una declaración judicial; no obstante, la especialidad del proceso monitorio plantea interrogantes a los que es necesario ofrecer respuesta.

\section{El despacho de ejecución}

Cuando el deudor no comparece ante el tribunal o no interpone oposición en el proceso monitorio se procede al despacho de la ejecución. Ello se lleva a cabo por medio de decreto del LAJ, dando por terminado el proceso monitorio y dando traslado al acreedor para que inste la ejecución. Para lo cual, sólo será necesario la mera solicitud (art. 816.1 LEC). Dicho de otro modo, es el decreto del LAJ que pone fin al proceso monitorio el que se constituye como título ejecutivo y que utilizará el acreedor para hacer valer su derecho mediante el proceso de ejecución correspondiente ${ }^{125}$.

Con anterioridad a la reforma de 2009 se planteaba la duda de si el tribunal podía o no iniciar de oficio el proceso ejecutivo sin necesidad de demanda ejecutiva por parte del acreedor. Hoy esta duda ha sido resuelta por el legislador, que exige la

\footnotetext{
${ }^{123}$ CORTÉS DOMÍNGUEZ, V. y MORENO CATENA, V., Derecho procesal civil, op. cit., pp. 31-32.

${ }^{124}$ MONTERO AROCA, J., El proceso civil, op. cit., pp. 1.303-1.307.

125 PLANCHADELL GARGALLO, A., La tutela del crédito..., op. cit., p. 161.
} 
solicitud del acreedor para incoar el proceso ejecutivo pertinente ${ }^{126}$. Sí plantea mayor problema la cuestión de si la solicitud de ejecución presentada por el acreedor se trata de una demanda de ejecución o de un simple trámite procesal. Planchadell considera que se trata de una auténtica demanda ejecutiva por sucinta que sea, y que habrán de indicarse los bienes del deudor susceptibles de embargo o las medidas oportunas para la averiguación y localización de los mismos, así como la posible existencia de terceros relacionados con la ejecución. Esto no siempre será sencillo y es posible que se necesite el asesoramiento de un profesional del derecho ${ }^{127}$.

Precisamente, este es otro de los interrogantes que merecen respuesta, esto es, si es necesaria postulación para la incoación del proceso ejecutivo. En este sentido, rige la regla general de que, si no se ha exigido abogado y procurador en caso de oposición en el proceso monitorio previo, tampoco será necesaria en el proceso ejecutivo; pero cuando haya sido precisa dicha defensa y representación a través de esos profesionales, sí será necesaria su intervención, es decir, para las deudas que superen los 2000 euros, como resuelve de forma específica el párrafo $2^{\circ}$ del art. 539.1 $\mathrm{LEC}^{128}$.

La solicitud de ejecución deberá presentarse en el plazo general señalado en el artículo 518 LEC, es decir, en los 5 años siguientes a la firmeza de la sentencia o resolución. Planchadell a este respecto entiende que un plazo tan amplio contradice la naturaleza del monitorio y que no tendría sentido esperar 5 años ni siquiera 20 días desde la emisión del título para instar la ejecución ${ }^{129}$.

Por último, es necesario precisar que el título ejecutivo no será únicamente el decreto del LAJ sino éste unido al requerimiento de pago no atendido; y se debe cuestionar si produce o no efecto de cosa juzgada. Puesto que no ha habido control alguno de fondo, no debería predicarse dicho efecto, pero sí que se produce una preclusión de las alegaciones. El artículo 816.2 establece que el solicitante del proceso monitorio y el deudor ejecutado no podrán pretender ulteriormente en proceso ordinario la cantidad reclamada en el monitorio o la devolución de la que con la ejecución se obtuviere. De manera que, sí se produce el efecto negativo o excluyente propio de la cosa juzgada ${ }^{130}$.

\section{La oposición a la ejecución}

Despachada ejecución el deudor tiene nuevamente la posibilidad de dar cumplimiento a su derecho de defensa y oponerse a la ejecución, si bien los motivos por los que podrá oponerse serán limitados pues se trata de un proceso ejecutivo de títulos judiciales. En estos casos, el legislador limita la defensa del deudor, ya que se ha celebrado un proceso en el que se ha discutido la cuestión material del litigio y se ha decidido contradictoriamente, por lo que no tiene sentido volver a discutir sobre lo mismo.

Esta oposición se estructura en dos grandes motivos: a) la oposición al conjunto de la ejecución y b) la oposición a actos ejecutivos concretos. En el primer

\footnotetext{
${ }^{126}$ BERMÚdEZ REQUENA, J.M., Proceso monitorio..., op. cit., p. 159.

${ }^{127}$ PLANCHADELL GARGALLO, A., La tutela del crédito ..., op. cit., p. 163.

${ }^{128}$ IBARRA SÁNCHEZ, J.L., Aspectos fundamentales del procedimiento ..., op. cit., p. 223.

${ }^{129}$ PLANCHADELL GARGALLO, A., La tutela del crédito ..., op. cit., p. 163.

${ }^{130}$ Ibidem, p. 65.
} 
caso, el deudor intenta poner fin al proceso ejecutivo alegando defectos procesales (los establecidos en el art. 599 LEC), o bien motivos de fondo que afecten directamente a la obligación documentada en el título pero que, en el caso de títulos judiciales, sólo puede oponerse la caducidad de la acción, el pago o cumplimiento de la obligación y los pactos o transacciones previamente convenidos para evitar la ejecución (art. 556 LEC). La tramitación de esta oposición revestirá la forma de un incidente procesal ${ }^{131}$. En el segundo caso, el deudor sólo podrá oponerse a determinados actos ejecutivos cuando se hayan infringido normas procesales acudiendo a los recursos legales establecidos en el artículo $562.1 .1^{\circ}$ y $2^{\circ}$ LEC, o bien mediante reposición y en su caso apelación (art. 562.1.3 ${ }^{\circ}$ LEC). Sólo excepcionalmente podrá solicitarse la nulidad de las actuaciones (art. 562.2 LEC). También podrá alegar el deudor la infracción del título ejecutivo cuando la acción ejecutiva no respete los términos del mismo ${ }^{132}$.

\section{CONCLUSIONES}

1. Del análisis histórico de la tradición procesal española se desprende que la técnica de inversión del contradictorio no ha sido desconocida en la práctica extralegal de nuestro país. Sin embargo, nunca ha tenido un reconocimiento expreso en la legislación, y esto, como pensaba Tomás y Valiente, puede deberse a un exceso de celo garantista o a una injustificada sobreprotección del deudor. A partir del año 2000, se introdujo el proceso monitorio como instrumento para la protección del crédito. Desde este mismo año, el legislador español se ha decantado por el modelo documental de este proceso en virtud del cual se exige una mínima acreditación escrita de la condición deudora.

2. Las reglas de competencia en el proceso monitorio destacan por su naturaleza imperativa y están dirigidas a garantizar el conocimiento por el deudor del procedimiento que se inicia contra él. Por ello, el tribunal competente será siempre el del domicilio del deudor y éste dispondrá de todas las herramientas procesales que garanticen su derecho de defensa en el proceso.

3. La iniciación del proceso monitorio se produce mediante la solicitud del acreedor, que deberá aportar un principio de prueba de su derecho, es decir, deberá justificar mínimamente su condición de acreedor y la existencia de la deuda. Si hay apariencia de buen derecho, la solicitud será admitida a trámite por el LAJ, quien requerirá al deudor para que en el plazo de 20 días responda a dicho requerimiento. El LAJ realiza un control procesal y documental del objeto del proceso, sobre todo a partir de la reforma del año 2015, lo que ha llevado a parte de la doctrina a considerar el proceso monitorio como un procedimiento judicial no jurisdiccional. No obstante, no debe olvidarse que siempre será el juez el que velará por la legalidad del procedimiento y será el director último del mismo; por ello, no puede negarse la naturaleza jurisdiccional de este procedimiento.

4. El proceso monitorio no es ajeno a la especial protección que merecen los negocios jurídicos celebrados con consumidores y usuarios y, por ello, se establece el control de oficio de las cláusulas del contrato que esté en la base de la petición monitoria. El juez podrá declarar el carácter abusivo de dichas cláusulas contractuales, previo incidente procesal, modificando así el objeto del proceso.

131 Ibidem, pp. 167-169.

132 Ibidem, p. 169. 
5. El requerimiento de pago es un acto de comunicación rigurosamente formal y este formalismo en la comunicación, tiene como finalidad principal acreditar que, efectivamente, el deudor tiene conocimiento del procedimiento iniciado en su contra. Por esta razón, siempre que no se acredite debidamente la recepción del mismo por el deudor, el procedimiento monitorio será archivado. A tal fin, la notificación se realizará mediante entrega personal (art. 161 LEC). De modo excepcional, se permite la publicación edictal del requerimiento de pago en los casos de deudas que tengan su origen en regímenes de propiedad horizontal, sencillamente, porque se presume que el domicilio del deudor coincide con la vivienda adscrita a este régimen y, aún en estos casos, la ley es especialmente proteccionista en cuanto a los actos de comunicación del requerimiento.

6. Tras la reforma del año 2015, el deudor debe oponerse fundadamente a la petición del acreedor; esto es, no basta con oponerse genéricamente y debe acreditar, aunque sea sucintamente, los motivos de su oposición. A juicio de la doctrina, esta motivación se justifica en los principios generales de buena fe y lealtad procesal, así como en la más elemental reciprocidad procesal e igualdad de las partes. Está claro que, si al acreedor tan solo se le exige que fundamente su petición documentalmente, sin exigir una detallada motivación, lo mismo habrá de exigirse al deudor que se opone, sin que esto suponga un menoscabo de su derecho de defensa.

7. Si se produce la oposición del deudor, la cuestión litigiosa podrá reproducirse en un juicio declarativo. Se tratará de un nuevo proceso judicial y, por tanto, no estará vinculado sustantivamente con el proceso monitorio, de modo que podrán alegarse nuevos hechos e incorporarse las pruebas pertinentes para la defensa del derecho de las partes; al menos en los casos en que la deuda reclamada esté en el ámbito del juicio ordinario (más de 6.000 euros). Porque esta regla se pone en entredicho cuando la deuda está en los márgenes del juicio verbal (hasta 6.000 euros), donde la cuestión litigiosa puede resolverse sin necesidad de celebrar vista, y donde el deudor no podrá alegar nuevos hechos ni pedir más pruebas que los que introduzca o solicite en el escrito de oposición. Para un sector de la doctrina esto rompe el equilibrio entre las partes, puesto que el acreedor dispone de dos momentos procesales para defender su derecho de crédito (el escrito de solicitud y la impugnación de la oposición) mientras que el deudor solo dispone del escrito de oposición para hacer valer su derecho.

8. La ejecución monitoria se trata de un proceso de ejecución dineraria basada en una declaración judicial; por este motivo, el deudor solo podrá oponerse en virtud de la caducidad de la acción, el pago de la obligación o la existencia de pacto entre las partes dirigido a evitar la ejecución; más los motivos procesales de oposición, con los que se discuta la existencia del derecho procesal al despacho del ejecutante.

9. La cuestión principal respecto al procedimiento monitorio es juzgar si la técnica de inversión del contradictorio supone o no una merma para el derecho de defensa del deudor. Parece que su tardía implantación en España responde a esta consideración peyorativa del proceso monitorio, entendiéndose que en el mismo se privilegia la condición de acreedor y se desprotege al deudor. A lo largo de este estudio se ha comprobado que esta alteración de la lógica procesal, en virtud de la cual es el deudor quien debe probar el cumplimiento de la obligación o la inexistencia del crédito, responde a la finalidad de acelerar el cumplimiento de las obligaciones o la rápida 
satisfacción del crédito, sin que por ello se transgredan los derechos de defensa del deudor. Es más, el derecho de defensa del deudor es una preocupación constante del legislador y no ha dejado de dotarle de herramientas y trámites oportunos para su correcta defensa. En este sentido, el deudor cuenta desde el inicio del procedimiento con las siguientes garantías para su defensa: la posibilidad de interponer declinatoria para atacar la competencia del tribunal, la necesaria acreditación de la deuda por parte del acreedor, la no admisibilidad de medidas cautelares, la asistencia preceptiva de abogado y procurador cuando la cuantía sea superior a $2.000 €$, el control del objeto del proceso por el LAJ, la especial protección que recibe en el caso de negocios jurídicos cuando sea consumidor o usuario, las rigurosas formalidades del acto de comunicación para garantizar el efectivo conocimiento del proceso monitorio, la posibilidad de oponerse fundadamente a la ejecución, etc.

\section{BIBLIOGRAFÍA}

AAVV., Comentarios a la nueva ley de enjuiciamiento civil, tomo III, Lex nova, 2001, Barcelona.

AAVV., Cuestiones prácticas sobre propiedad horizontal. Memento experto, Francis Lefevbre, 2014, Madrid.

AAVV., Derecho jurisdiccional II. Proceso civil, 25 ed., Tirant lo Blanch, 2017, Valencia.

ARMENTA DEU, T., Lecciones de Derecho Procesal Civil, Marcial Pons, 2017, Madrid.

BERMÚDEZ REQUENA, J.M., Proceso monitorio. Evolución legislativa, doctrinal y jurisprudencial. Jurúa, 2017, Lisboa.

BONET NAVARRO, J., "Monitorio y juicio verbal para sustanciar la oposición conforme a la ley 42/2015 de 5 de octubre”, Diario la Ley, n. 8810, (2016).

BONET NAVARRO, J., "La relativa autonomía del juicio que corresponda tras la oposición en los procedimientos monitorios", Problemas actuales del proceso iberoamericano, I., Actas, Málaga, 2006.

CASTILLO FELIPE, R., La oposición a la ejecución por defectos procesales: estudio del art. 559 LEC, Thomson Reuter Aranzadi, 2017, Pamplona.

CORREA DELCASSO, J.P., "El proceso monitorio en el Derecho comparado: diez puntos clave para su correcta implementación en los países de América Latina", en AAVV., El proceso monitorio en América Latina. Pasado, presente y futuro, Temis, 2013, Bogotá.

CORTÉS DOMÍNGUEZ, V. y MORENO CATENA, V., Derecho procesal civil. Parte especial, 9a ed., Tirant lo Blanch, 2017, Valencia.

CUBILlO LÓPEZ, I., Aspectos fundamentales del derecho procesal civil, La Ley, 2016, Madrid. 
FRAGA MANDIÁN, A., "Cláusulas abusivas y cosa juzgada”, Proceso Civil, Segundo trimestre, n. 123, (2016).

GARCÍA CANO, S., Estudio sobre el Proceso Monitorio Europeo, Thomson Reuters Aranzadi, 2008, Pamplona.

GIMENO SENDRA, V., Introducción al derecho procesal, UNED, 2015, Madrid.

GÓMEZ AMIGO, L., El Proceso Monitorio Europeo, Thomson Reuters Aranzadi, 2008, Pamplona.

GÓMEZ AMIGO, L., "La evolución del proceso monitorio. En particular, su reforma por la ley 42/2015 de 5 de octubre". Práctica de tribunales, n. 126, (2017).

GÓMEZ COLOMER, J.L., "Comentarios prácticos a los artículos 812 a 818 del capítulo I del título III del libro IV de la Ley de Enjuiciamiento Civil: del proceso monitorio", en SOLAZ, E., Ejecución de títulos extrajudiciales. Juicio cambiario y monitorio, Consejo General del Poder Judicial, 2005, Madrid.

HERRERO PEREZAGUA, J., Las Transformaciones del proceso civil, Thomson Reuters Aranzadi, 2017, Pamplona.

HERRERO PEREZAGUA, J., "5 preguntas sobre la transformación del monitorio", Revista General de Derecho Procesal, n. 45, (2018).

IBARRA SÁNCHEZ, J.L., Aspectos fundamentales del procedimiento monitorio civil, La Ley, 2016, Madrid.

JUAN SÁNCHEZ, R., Introducción al derecho procesal, Aranzadi, 2017, Pamplona.

LARA HERNÁNDEZ, R., "Sin la toga”, Revista actualidad jurídica Aranzadi, n. 907, (2015).

LÓPEZ SÁNCHEZ, J., El proceso monitorio, La ley, 2000, Madrid.

MARTÍNEZ BELTRÁN DE HEREDIA, F., El proceso monitorio. Teoría y práctica, Difusión jurídica y temas de actualidad, 2007, Madrid.

MONTERO AROCA, J., El proceso civil. Los procesos ordinarios de declaración y de ejecución, Tirant lo blanch, 2016, Valencia.

OLIVA SANTOS, A., DÍEZ-PICAZO GIMÉNEZ, I. y VEGAS TORRES, J., Las especialidades procedimentales de los procesos ordinarios, Curso de Derecho Procesal Civil II. Parte especial, Ramón Areces, 2016, Madrid.

PAZOS CASTRO, R., El control de las cláusulas abusivas en los contratos con consumidores, Aranzadi, 2017, Pamplona. 
PEITEADO MARISCAL, P. y CUBILLO LÓPEZ, I., Instrumentos procesales para la tutela judicial del crédito, Dykinson, 2018, Madrid.

PICÓ I JUNOY, J., "Nuevas perspectivas sobre la debida armonización del proceso monitorio y el posterior juicio ordinario", Revista justicia, n.1, (2013).

PICÓ I JUNOY, J., “Réquiem por el proceso monitorio”, Justicia, n. 2, (2015).

PLANCHADELL GARGALLO, A., La tutela del crédito en el proceso monitorio, La Ley, 2015, Madrid.

QUÍLEZ MORENO, J.M., El proceso monitorio: estudio doctrinal, jurisprudencial y futura realidad de la e-justicia, La Ley, 2011, Madrid.

TOMÁS Y VALIENTE, F., "Estudio histórico-jurídico del proceso monitorio", Revista de Derecho Procesal, (1960). 